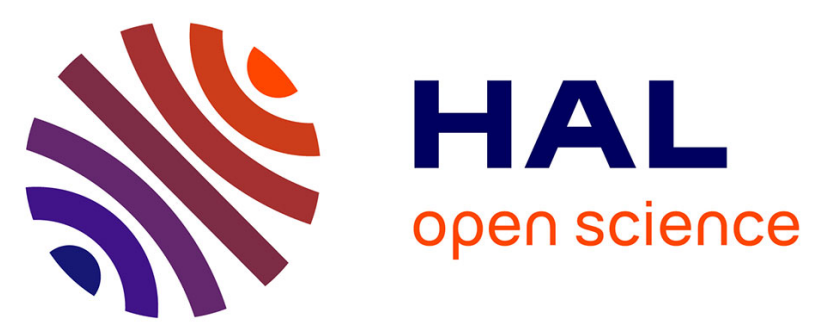

\title{
Structural, NMR, IR, Hirshfeld surface, electrochemical and in vitro biochemical investigations of a new organic cyclohexaphosphate, (C6H6ClFN 4 (Li) 2(P6O18)(H2O) 4
}

L. Khedhiri, A. Gannouni, M Khalfaoui, Christian Jelsch, V. Ferretti, Fabrice Lefebvre, C. Ben Nasr

\section{To cite this version:}

L. Khedhiri, A. Gannouni, M Khalfaoui, Christian Jelsch, V. Ferretti, et al.. Structural, NMR, IR, Hirshfeld surface, electrochemical and in vitro biochemical investigations of a new organic cyclohexaphosphate, (C6H6ClFN)4 (Li)2(P6O18)(H2O)4. Journal of the Iranian Chemical Society, 2021, 18 (4), pp.933-947. 10.1007/s13738-020-02078-8 . hal-02971689

\section{HAL Id: hal-02971689 \\ https://hal.science/hal-02971689}

Submitted on 19 Oct 2020

HAL is a multi-disciplinary open access archive for the deposit and dissemination of scientific research documents, whether they are published or not. The documents may come from teaching and research institutions in France or abroad, or from public or private research centers.
L'archive ouverte pluridisciplinaire HAL, est destinée au dépôt et à la diffusion de documents scientifiques de niveau recherche, publiés ou non, émanant des établissements d'enseignement et de recherche français ou étrangers, des laboratoires publics ou privés. 
DOI : $10.1007 / \mathrm{s} 13738-020-02078-8$

\section{Structural, NMR, IR, Hirshfeld Surface, Electrochemical and in Vitro}

\section{Biochemical Investigations of a New Organic Cyclohexaphosphate,}

\section{$\left(\mathrm{C}_{6} \mathrm{H}_{6} \mathrm{ClFN}\right)_{4}(\mathrm{Li})_{2}\left(\mathrm{P}_{6} \mathrm{O}_{18}\right)\left(\mathrm{H}_{2} \mathrm{O}\right)_{4}$}

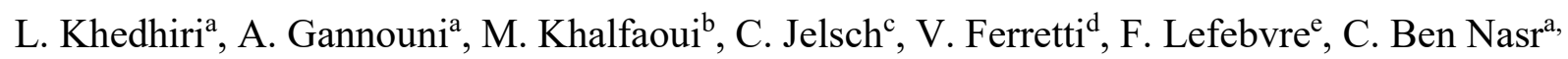

${ }^{a}$ Laboratoire de Chimie des Matériaux, Faculté des Sciences de Bizerte, 7021 Zarzouna, Université de Carthage, Tunisie.

${ }^{\mathrm{b}}$ Common Service Unit Surface Spectrometer, Faculty of Sciences of Bizerte, University of Carthage, Zarzouna 7021, Tunisia.

${ }^{\mathrm{c}} \mathrm{CRM}^{2}$, CNRS, Institut Jean Barriol, Université de Lorraine, Nancy, France.

d Department of Chemical and Pharmaceutical Sciences and Center for Structural Diffractometry, via Fossato di Mortara 17, I-44121 Ferrara, Italy

${ }^{\text {e} L a b o r a t o i r e ~ d e ~ C h i m i e ~ O r g a n o m e ́ t a l l i q u e ~ d e ~ S u r f a c e ~(L C O M S), ~ E c o l e ~ S u p e ́ r i e u r e ~ d e ~ C h i m i e ~}$ Physique Electronique, 69626 Villeurbanne Cedex, France.

Corresponding e-mail: cherif bennasr@yahoo.com 


\begin{abstract}
The new organic cyclohexaphosphate $\left(\mathrm{C}_{6} \mathrm{H}_{7} \mathrm{ClFN}\right)_{4}(\mathrm{Li})_{2}\left(\mathrm{P}_{6} \mathrm{O}_{18}\right)\left(\mathrm{H}_{2} \mathrm{O}\right)_{4}$, has been synthesized at room temperature by an acid/base reaction between $\mathrm{H}_{6} \mathrm{P}_{6} \mathrm{O}_{18}$ and 3-chloro-4fluoroaniline as an organic template. The crystal structure of $\left(\mathrm{C}_{6} \mathrm{H}_{7} \mathrm{ClFN}\right)_{4}(\mathrm{Li})_{2}\left(\mathrm{P}_{6} \mathrm{O}_{18}\right)\left(\mathrm{H}_{2} \mathrm{O}\right)_{4}$ was solved by single crystal X-ray diffraction analysis. A double head-to-head layer of cations is formed by hydrophobic interactions. Hirshfeld surface analysis reveals the nature of intermolecular contacts of the title compound. The contacts enrichment ratio shows that both strong electrostatic interactions and hydrophobic contacts are over-represented. This hybrid material was then characterized by ${ }^{1} \mathrm{H},{ }^{13} \mathrm{C},{ }^{31} \mathrm{P},{ }^{15} \mathrm{~N}$ and ${ }^{19} \mathrm{~F}$ solid-state NMR and IR spectroscopies. Electrical conductivity was also studied using impedance spectroscopy and results showed that the conductivity at $105^{\circ} \mathrm{C}$ was equal to $96.5 \times 10^{-4} \mathrm{~S}_{\mathrm{cm}} \mathrm{cm}^{-1}$. Antioxidant properties of this compound were studied, in vitro, at various concentrations with different tests; 1,1-diphenyl-2-picrylhydrazyl (DPPH), Ferric reducing power (FRAP), Trolox equivalent antioxidant capacity (TEAC) or $\mathrm{ABTS}^{+}$, using 6-hydroxy-2,5,7,8-tetramethylchroman-2carboxylic acid (Trolox) as control.
\end{abstract}

Keywords: Cyclohexaphosphate; Hirshfeld surface; Contacts enrichment; ${ }^{31} \mathrm{P}$ MAS-NMR; Infrared spectroscopy; Electrical conductivity; Antioxidant properties. 


\section{Introduction}

Organic-inorganic compounds have been studied extensively in recent years owing to their interesting properties by the inclusion of both the inorganic and organic components into a product. These compounds have attracted great attention because of their unique opportunity to combine the remarkable features of organic compounds with those of inorganic materials. Hybrid materials based on phosphates have received much attention in recent years due to their technological interest in several areas such as magnetism, electricity, battery, optics and biomaterials research $[1,2]$. The properties of the organic molecule, such as length, geometry and relative position of the donor groups, play a very important role in the production of various hybrid compounds with interesting three-dimensional networks, layers, chains and ribbons structures [3-6]. The cohesion forces in these hybrid compounds are dominated by electrostatic interactions, Van der Waals contacts, and hydrogen bonds (O-H... O, N-H...O).

Cyclohexaphosphates were shown to be potentially attractive as precursors in the solidstate synthesis of simple and mixed-cation polyphosphates for glass making [7, 8]. In this area, the literature reports several cyclohexaphosphates of mixed cations associating the lithium molecules which have been known and structurally characterized [9-13]. This family of compounds which exhibit a rich structural diversity can be further used in lithium batteries [14].

In planning the synthesis of a new organic cyclohexaphosphate, the choice of the organic cation felt on aniline derivatives. Indeed, aniline is an important organic chemical commodity. Main applications are in polymer chemistry; however, production of rubber chemicals, dyes, pharmaceuticals, and other chemical specialties is also important. It has been widely studied for its use in electrical conduction, electroluminescence, rechargeable batteries and anti-corrosion applications [15-17]. 


\section{Experimental}

\section{Chemical Preparation}

$10 \mathrm{~mL}(2 \mathrm{mmol})$ of an aqueous solution of cyclohexaphosphoric acid, prepared by passing a solution of $\mathrm{Li}_{6} \mathrm{P}_{6} \mathrm{O}_{18}$, elaborated by Schülke's method [18], through an ion exchange resin (Amberlite IR120) in its H-state, were neutralized by adding slowly 3-chloro-4fluoroaniline, (purity 97\%) from Sigma-Aldrich, $(8 \mathrm{mmol}$ ) dissolved in $5 \mathrm{~mL}$ of ethanol which is supplied by Novachim. The resulting solution is then slowly evaporated over few days at ambient temperature to give large rectangular prisms of stable crystals of $\left(\mathrm{C}_{6} \mathrm{H}_{6} \mathrm{ClFN}\right)_{4}$ $(\mathrm{Li})_{2}\left(\mathrm{P}_{6} \mathrm{O}_{18}\right)\left(\mathrm{H}_{2} \mathrm{O}\right)_{4}($ yield $=85 \%)$. The elemental analysis method was applied to determine the proposed formula of the obtained crystals: N, 4.77\%/4.88\% (exp./theor.); C, 25.38\%/25.13\%; $\mathrm{H}, 2.86 \% / 2.79 \%$

An incomplete $\mathrm{Li}^{+} / \mathrm{H}^{+}$exchange of $\mathrm{Li}_{6} \mathrm{P}_{6} \mathrm{O}_{18}$ on the used resin can explain the lithium existence in title cyclohexaphosphates.

\section{X-Ray Single Crystal Structure Analysis}

The crystallographic data were collected at room temperature using graphitemonochromated MoK $\alpha$ radiation $(\lambda=0.71073 \AA$ ) with a $\varphi$ scan followed by $\omega$ scan to fill the sphere. Data sets were integrated with the Denzo-SMN package [19] and corrected for Lorenz, polarization and absorption effects. The structure was solved by direct methods with the SIR97 program [20] and refined on $F^{2}$ by full-matrix least-squares methods with anisotropic non-H atoms. The hydrogen atoms linked to the aniline nitrogen, as well as those belonging to water molecules, were found in the Difference Fourier map and refined isotropically. All other hydrogen atoms were included on calculated positions, riding on their carrier atoms. All calculations were performed using SHELXL-2014/7 [21] implemented in the WINGX system of programs [22]. The crystal data are reported in Table S1. The drawings were made with Diamond [23]. 


\section{NMR and IR measurements}

The solid-state ${ }^{13} \mathrm{C},{ }^{15} \mathrm{~N}$ and ${ }^{31} \mathrm{P}$ NMR spectra were recorded by using cross-polarization (CP) and decoupling from protons (contact time $2 \mathrm{~ms}$ ) while the ${ }^{19} \mathrm{~F}$ spectrum was obtained by direct irradiation. A ${ }^{31} \mathrm{P}$ NMR spectrum was also recorded by direct irradiation and proton decoupling (recycle delay $100 \mathrm{~s}$ ) and did not show any difference with that recorded by CP. ${ }^{31} \mathrm{P}$ MAS-NMR spectrum analysis was carried out by using the Bruker program WINFIT [24]. The IR spectrum was recorded in the $4000-400 \mathrm{~cm}^{-1}$ range.

\section{Electrical measurements}

The impedance measurements were taken in an open circuit using two electrode configurations with a signal amplitude of $50 \mathrm{mV}$ and a frequency band ranging from $5 \mathrm{~Hz}$ to $13 \mathrm{MHz}$. Both pellet surfaces were coated with silver paste electrodes while the platinum wires attached to the electrodes were used as current collectors. The measurements were performed at equilibrium potential at a temperature ranging between 298 and $368 \mathrm{~K}$. In order to obtain the ionic conductivity, the resulting data was analyzed using the equivalent circuit of the Z-View software.

\section{Instruments}

The crystallographic data were collected on a Nonius Kappa CCD diffractometer. The solidstate NMR spectra were recorded on a solid-state high-resolution Bruker Avance-500 spectrometer. The IR spectrum was recorded using a NICOLET IR 200 FT-IR infrared spectrometer. Impedance spectra (IS) were obtained using a Hewlett-Packard HP 4192 analyzer. 


\section{Results and Discussion}

\section{Structure description}

The asymmetric unit of $\left(\mathrm{C}_{6} \mathrm{H}_{6} \mathrm{ClFN}\right)_{4}(\mathrm{Li})_{2}\left(\mathrm{P}_{6} \mathrm{O}_{18}\right)\left(\mathrm{H}_{2} \mathrm{O}\right)_{4}$ includes two half of the phosphoric rings lying on inversion centers $(0,1 / 2,0)$ and $(1 / 2,0,0)$, two lithium atoms, four water molecules among which $\mathrm{O} 1 \mathrm{~W}$ and $\mathrm{O} 2 \mathrm{~W}$ are coordinated to the $\mathrm{Li}$ atoms and four 3chloro-4-fluoroanilinium cations. An ORTEP design of these species is shown in Fig. 1.

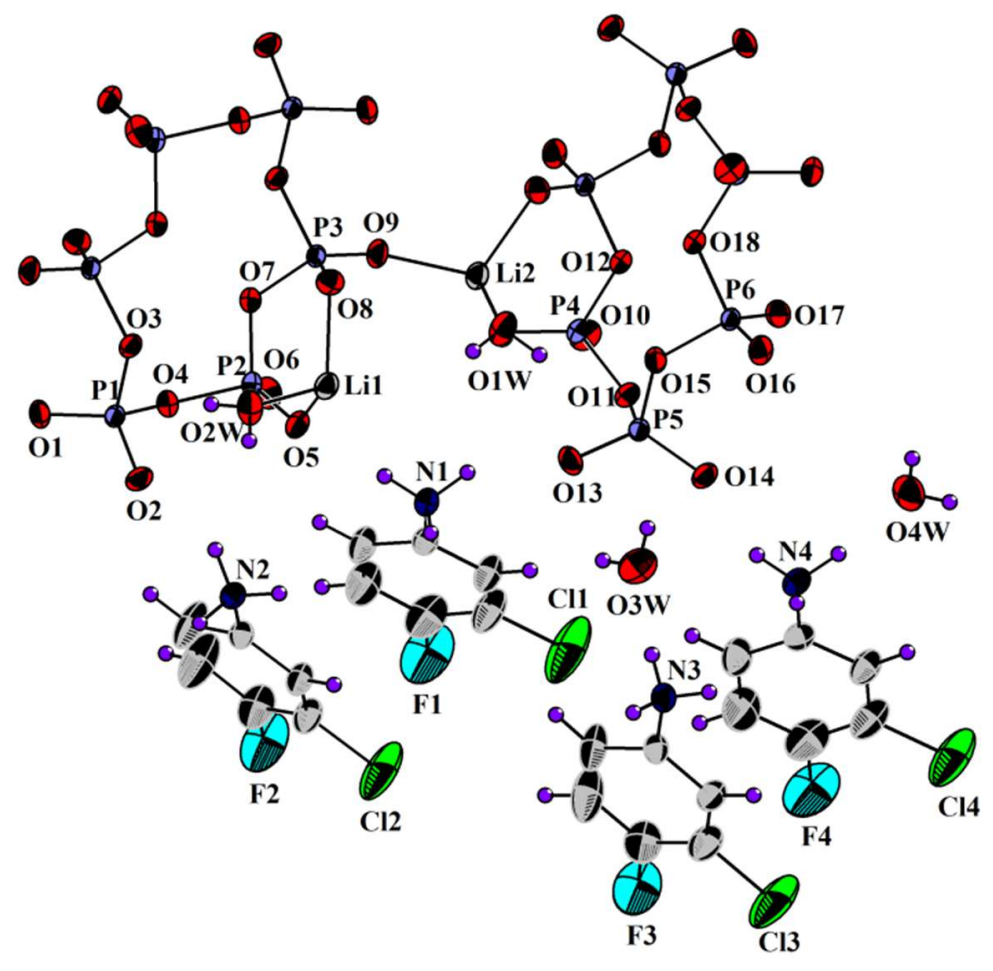

Fig. 1: ORTEP view of $\left(\mathrm{C}_{6} \mathrm{H}_{6} \mathrm{ClFN}\right)_{4}(\mathrm{Li})_{2} \mathrm{P}_{6} \mathrm{O}_{18} .4 \mathrm{H}_{2} \mathrm{O}$. Displacement ellipsoids are drawn at the $40 \%$ probability level and $\mathrm{H}$ atoms are shown as small spheres of arbitrary radii.

As shown in Fig. 2, the phosphoric rings are linked by lithium atoms and water molecules via sharing some oxygen corners generating a two-dimensional inorganic framework parallel to the $(\mathbf{a}, \mathbf{b})$ plane 


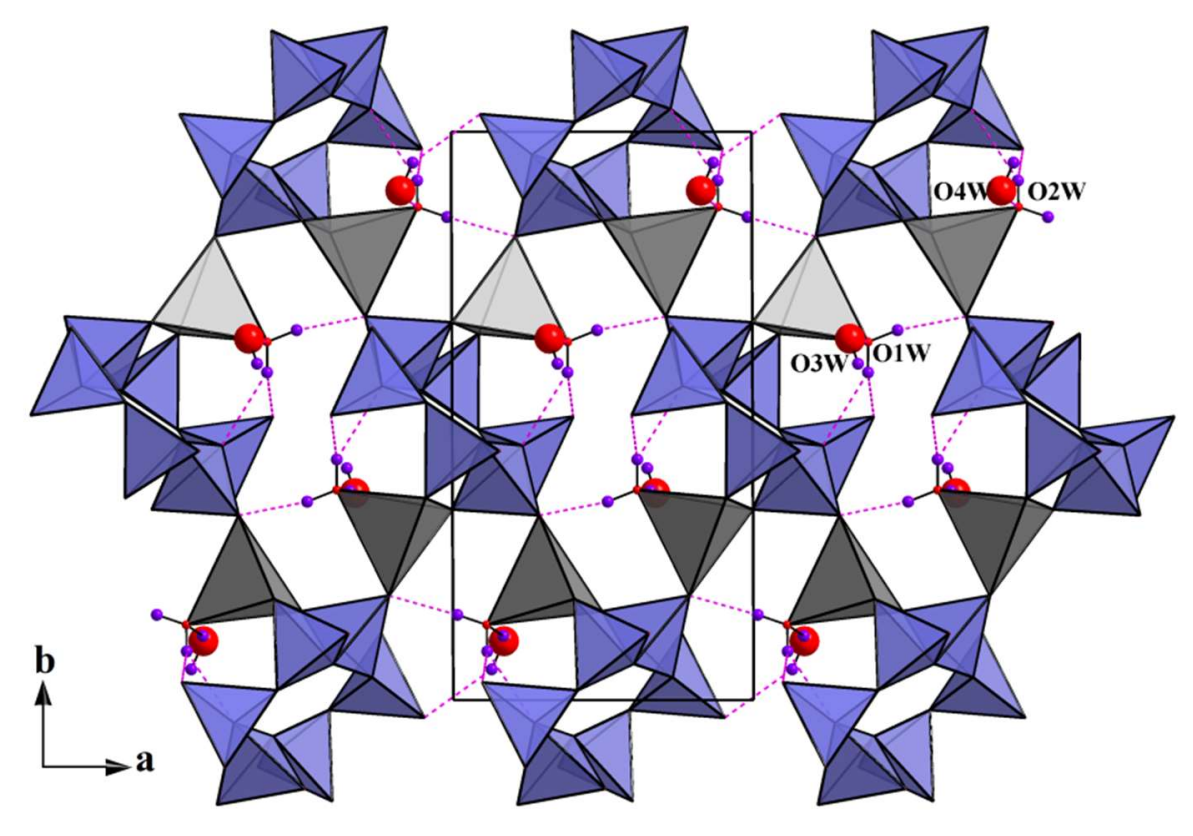

Fig. 2: Projection along the $c$-axis, of an inorganic layer in the structure of

$$
\left(\mathrm{C}_{6} \mathrm{H}_{6} \mathrm{ClFN}\right)_{4}(\mathrm{Li})_{2}\left(\mathrm{P}_{6} \mathrm{O}_{18}\right)\left(\mathrm{H}_{2} \mathrm{O}\right)_{4}
$$

Each $\mathrm{P}_{6} \mathrm{O}_{18}$ ring anion is formed by three independent $\mathrm{PO}_{4}$ tetrahedra and adopts a chair conformation. The geometric features of the phosphoric rings are listed in Table 1. The P-O distances range from 1.4741(1) to 1.6053(1) $\AA$ with an average of $1.540 \AA$. These differences in $\mathrm{P}-\mathrm{O}$ distances can be explained by the different environment of the $\mathrm{O}$ atoms. Calculated average values of the distortion indices (DI) [25] in the $\mathrm{P}_{6} \mathrm{O}_{18}$ anion are given in Table 2. The $\mathrm{DI}(\mathrm{PO})=0.039, \mathrm{DI}(\mathrm{OPO})=0.037$ and $\mathrm{DI}(\mathrm{OO})=0.012$ values show an above distortion of the O-O distances compared to P-O ones. Furthermore, each $\mathrm{PO}_{4}$ tetrahedron can be described by regular oxygen atoms arrangement with phosphorus atom shifted by $0.131,0.162,0.136,0.131$, 0.161 and $0.137 \AA$ from the gravity center (Table 2 ). The P-O-P angle values are comparable to those observed in similar cyclohexaphosphates [26, 27], with the exception of the P1-O1-P2 and P4-O10-P5 angles of $141.50(1)^{\circ}$ each, significantly different from the value generally observed in such anions. These angles are associated with the longest P1-P2 and P4-P5 distances (2.991(3) $\AA$ ). It should be noted that these values display the greatest divergence 
observed so far. The P-P-P angles, ranging from $96.40(3)$ to $109.37(3)^{\circ}$, clearly indicate that the rings are significantly distorted from the ideal three-fold symmetry. In spite of this variance, the distortion is less important if compared with that observed in $\left(\mathrm{C}_{8} \mathrm{H}_{12} \mathrm{~N}\right)_{4}(\mathrm{Li})_{2}\left(\mathrm{P}_{6} \mathrm{O}_{18}\right)\left(\mathrm{H}_{2} \mathrm{O}\right)_{6}$ [28], in which the average of the P-P-P angle is $107.05^{\circ}$.

Table 1. Interatomic distances $(\AA)$ and bond angles $\left(^{\circ}\right)$ in $\left(\mathrm{C}_{6} \mathrm{H}_{6} \mathrm{ClFN}\right)_{4}(\mathrm{Li})_{2} \mathrm{P}_{6} \mathrm{O}_{18} \cdot 4 \mathrm{H}_{2} \mathrm{O}$. P-O distances are on the diagonal, O-P-O angles and O-O distances are above and below the diagonal, respectively.

\section{Tetrahedron $\mathrm{P}(1) \mathrm{O}_{4}$}

\begin{tabular}{|l|c|c|c|c|}
\hline P1 & O1 & O3 & O4 & O5 \\
\hline O1 & $1.6036(1)$ & $102.62(7)^{\circ}$ & $110.63(7)^{\circ}$ & $105.74(8)^{\circ}$ \\
\hline O3 & $2.500(6)$ & $1.6026(1)$ & $105.96(7)^{\circ}$ & $110.69(8)^{\circ}$ \\
\hline O4 & $2.560(7)$ & $2.509(3)$ & $1.4799(1)$ & $119.91(8)^{\circ}$ \\
\hline O5 & $2.498(1)$ & $2.464(3)$ & $2.473(2)$ & $1.4799(1)$ \\
\hline
\end{tabular}

\section{Tetrahedron $\mathrm{P}(2) \mathrm{O}_{4}$}

\begin{tabular}{|l|c|c|c|c|}
\hline P2 & O1 & O2 & O6 & O7 \\
\hline O1 & $1.6053(1)$ & $110.83(7)^{\circ}$ & $111.86(7)^{\circ}$ & $108.34(7)^{\circ}$ \\
\hline O2 & $2.503(3)$ & $1.6020(1)$ & $110.83(7)^{\circ}$ & $108.08(8)^{\circ}$ \\
\hline O6 & $2.451(2)$ & $2.530(3)$ & $1.4741(1)$ & $119.08(8)^{\circ}$ \\
\hline O7 & $2.474(4)$ & $2.460(7)$ & $2.553(5)$ & $1.4907(1)$ \\
\hline
\end{tabular}

\section{Tetrahedron $\mathrm{P}(3) \mathrm{O}_{4}$}

\begin{tabular}{|c|c|c|c|c|}
\hline P3 & O2 & O3 & O8 & O9 \\
\hline O2 & $1.6013(1)$ & $100.01(7)^{\circ}$ & $108.83(7)^{\circ}$ & $110.52(8)^{\circ}$ \\
\hline O3 & $2.443(6)$ & $1.5978(1)$ & $111.15(8)^{\circ}$ & $106.02(7)^{\circ}$ \\
\hline O8 & $2.430(4)$ & $2.490(5)$ & $1.4917(1)$ & $118.69(8)^{\circ}$ \\
\hline O9 & $2.514(8)$ & $2.503(3)$ & $2.522(4)$ & $1.4782(1)$ \\
\hline
\end{tabular}

\section{$\underline{\text { Tetrahedron } \mathrm{P}(4) \mathrm{O}_{4}}$}

\begin{tabular}{|c|c|c|c|c|}
\hline P4 & O10 & O12 & O13 & O14 \\
\hline O10 & $1.6012(1)$ & $102.81(7)^{\circ}$ & $110.64(8)^{\circ}$ & $105.45(8)^{\circ}$ \\
\hline $\mathbf{O 1 2}$ & $2.500(6)$ & $1.6038(1)$ & $105.35(7)^{\circ}$ & $111.16(8)^{\circ}$ \\
\hline
\end{tabular}




\begin{tabular}{|l|l|l|l|l|}
\hline $\mathbf{O 1 3}$ & $2.560(7)$ & $2.509(3)$ & $1.4783(1)$ & $120.15(8)^{\circ}$ \\
\hline $\mathbf{O 1 4}$ & $2.498(1)$ & $2.464(3)$ & $2.473(2)$ & $1.4801(1)$ \\
\hline
\end{tabular}

Tetrahedron $\mathrm{P}(5) \mathrm{O}_{4}$

\begin{tabular}{|c|c|c|c|c|}
\hline P5 & O10 & O11 & O15 & O16 \\
\hline O10 & $1.6024(1)$ & $96.07(7)^{\circ}$ & $111.92(7)^{\circ}$ & $108.37(7)^{\circ}$ \\
\hline O11 & $2.503(3)$ & $1.6019(1)$ & $110.76(8)^{\circ}$ & $108.31(8)^{\circ}$ \\
\hline O15 & $2.451(2)$ & $2.530(3)$ & $1.4764(1)$ & $118.96(8)^{\circ}$ \\
\hline O16 & $2.474(4)$ & $2.460(7)$ & $2.553(5)$ & $1.4886(1)$ \\
\hline
\end{tabular}

$\underline{\text { Tetrahedron } \mathrm{P}(6) \mathrm{O}_{4}}$

\begin{tabular}{|c|c|c|c|c|}
\hline P6 & O11 & O12 & O17 & O18 \\
\hline O11 & $1.6020(1)$ & $100.21(7)^{\circ}$ & $108.52(7)^{\circ}$ & $110.26(8)^{\circ}$ \\
\hline O12 & $2.443(6)$ & $1.5969(1)$ & $111.29(8)^{\circ}$ & $105.89(8)^{\circ}$ \\
\hline O17 & $2.430(4)$ & $2.490(5)$ & $1.4928(1)$ & $119.04(8)^{\circ}$ \\
\hline $\mathbf{O 1 8}$ & $2.514(8)$ & $2.503(3)$ & $2.522(4)$ & $1.4781(1)$ \\
\hline
\end{tabular}

$\underline{\text { Tetrahedron } \mathrm{Li}(1) \mathrm{O}_{4}}$

\begin{tabular}{|c|c|c|c|c|}
\hline Li1 & O6 & O8 & O16 & O2W \\
\hline O6 & $1.937(4)$ & $101.83(2)^{\circ}$ & $111.13(2)^{\circ}$ & $109.82(2)^{\circ}$ \\
\hline O8 & $3.275(3)$ & $1.994(3)$ & $110.39(2)^{\circ}$ & $108.85(2)^{\circ}$ \\
\hline O16 & $3.133(7)$ & $3.049(4)$ & $1.877(3)$ & $114.11(2)^{\circ}$ \\
\hline O2W & $3.182(5)$ & $3.164(5)$ & $3.182(4)$ & $1.939(4)$ \\
\hline
\end{tabular}

\section{$\underline{\text { Tetrahedron Li(2) } \mathrm{O}_{4}}$}

\begin{tabular}{|c|c|c|c|c|}
\hline Li2 & O7 & O15 & O1W & O17 \\
\hline O7 & $1.881(3)$ & $112.14(2)^{\circ}$ & $113.65(2)^{\circ}$ & $107.28(2)^{\circ}$ \\
\hline $\mathbf{O 1 5}$ & $3.264(3)$ & $1.936(4)$ & $109.91(2)^{\circ}$ & $101.96(2)^{\circ}$ \\
\hline
\end{tabular}




\begin{tabular}{|c|c|c|c|c|}
\hline O1W & $3.122(7)$ & $3.051(4)$ & $1.935(4)$ & $111.26(2)^{\circ}$ \\
\hline $\mathbf{O 1 7}$ & $3.191(5)$ & $3.152(5)$ & $3.172(4)$ & $2.015(4)$ \\
\hline
\end{tabular}

\begin{tabular}{llllll}
\hline P1-P2 & $2.991(3)$ & P1-O1-P2 & $141.50(1)^{\circ}$ & P1-P2-P3 & $109.03(3)^{\circ}$ \\
P2-P3 & $2.977(7)$ & P1-O3-P3 & $133.05(9)^{\circ}$ & P2-P3-P1 & $109.37(3)^{\circ}$ \\
P3-P1 & $2.926(5)$ & P3-O2-P2 & $138.16(1)^{\circ}$ & P3-P1-P2 & $96.40(3)^{\circ}$ \\
P4-P5 & $2.991(3)$ & P4-O10-P5 & $141.50(1)^{\circ}$ & P4-P5-P6 & $109.03(3)^{\circ}$ \\
P5-P6 & $2.977(7)$ & P5-O11-P6 & $133.05(9)^{\circ}$ & P5-P6-P4 & $109.37(3)^{\circ}$ \\
P4-P6 & $2.926(5)$ & P4-O12-P6 & $138.16(1)^{\circ}$ & P6-P4-P5 & $96.40(3)^{\circ}$ \\
\hline
\end{tabular}


Table 2. Interatomic PO distances $(\AA)$, OPO angles $\left(^{\circ}\right)$ tetrahedral distortion indexes $\mathrm{ID}(\mathrm{PO})$, $\mathrm{ID}(\mathrm{OPO})$ and $\mathrm{ID}(\mathrm{OO})$ of $\left(\mathrm{C}_{6} \mathrm{H}_{7} \mathrm{ClFN}\right)_{4}(\mathrm{Li})_{2}\left(\mathrm{P}_{6} \mathrm{O}_{18}\right)\left(\mathrm{H}_{2} \mathrm{O}\right)_{4}$

\begin{tabular}{|c|c|c|c|c|c|c|c|}
\hline $\mathbf{P}(\mathbf{i}) \mathbf{O}_{4}$ & $<\mathbf{P}-\mathbf{O}>(\AA)$ & $<\mathbf{O}-\mathbf{O}>(\mathbf{\AA})$ & $\left.<\mathbf{O}-\mathbf{P}-\mathbf{O}>\mathbf{(}^{(}\right)$ & $\mathbf{I D}(\mathbf{P O})$ & $\mathbf{I D}(\mathbf{O O})$ & $\mathbf{I D}(\mathbf{O P O})$ & $\boldsymbol{\delta}(\AA)$ \\
\hline $\mathbf{P}(\mathbf{1}) \mathbf{O}_{4}$ & 1.542 & 2.510 & 109.26 & 0.04 & 0.014 & 0.041 & 0.131 \\
\hline $\mathbf{P ( 2 )} \mathbf{O}_{4}$ & 1.538 & 2.507 & 109.06 & 0.04 & 0.015 & 0.045 & 0.162 \\
\hline $\mathbf{P ( 3 ) \mathbf { O } _ { 4 }}$ & 1.542 & 2.510 & 109.89 & 0.037 & 0.015 & 0.045 & 0.136 \\
\hline $\mathbf{P ( 4 )} \mathbf{O}_{4}$ & 1.541 & 2.509 & 109.26 & 0.04 & 0.015 & 0.034 & 0.131 \\
\hline $\mathbf{P ( 5 )} \mathbf{O}_{4}$ & 1.542 & 2.506 & 109.07 & 0.038 & 0.016 & 0.044 & 0.161 \\
\hline $\mathbf{P ( 6 )} \mathbf{O}_{4}$ & 1.543 & 2.510 & 110.87 & 0.036 & 0.014 & 0.026 & 0.137 \\
\hline
\end{tabular}

In Figs. 3 and 4, the complete atomic arrangement of the structure projected along the $b$ and $a$ axis respectively is exhibited. These projections show that the packing of $\left(\mathrm{C}_{6} \mathrm{H}_{6} \mathrm{ClFN}\right)_{4}$ (Li) $)_{2}\left(\mathrm{P}_{6} \mathrm{O}_{18}\right)\left(\mathrm{H}_{2} \mathrm{O}\right)_{4}$ consists of two hybrid layers: the first one, developed parallel to the $(\mathbf{a}, \mathbf{b})$ plane around $z=0$, is made of inorganic $\left[\mathrm{Li}_{2} \mathrm{P}_{6} \mathrm{O}_{18} \cdot \mathrm{H}_{2} \mathrm{O}\right]^{4-}$ entities. The second one, sandwiched in the space between the inorganic layers, is built of organic $\left[\mathrm{C}_{6} \mathrm{H}_{6} \mathrm{ClFN}\right]^{+}$cations.

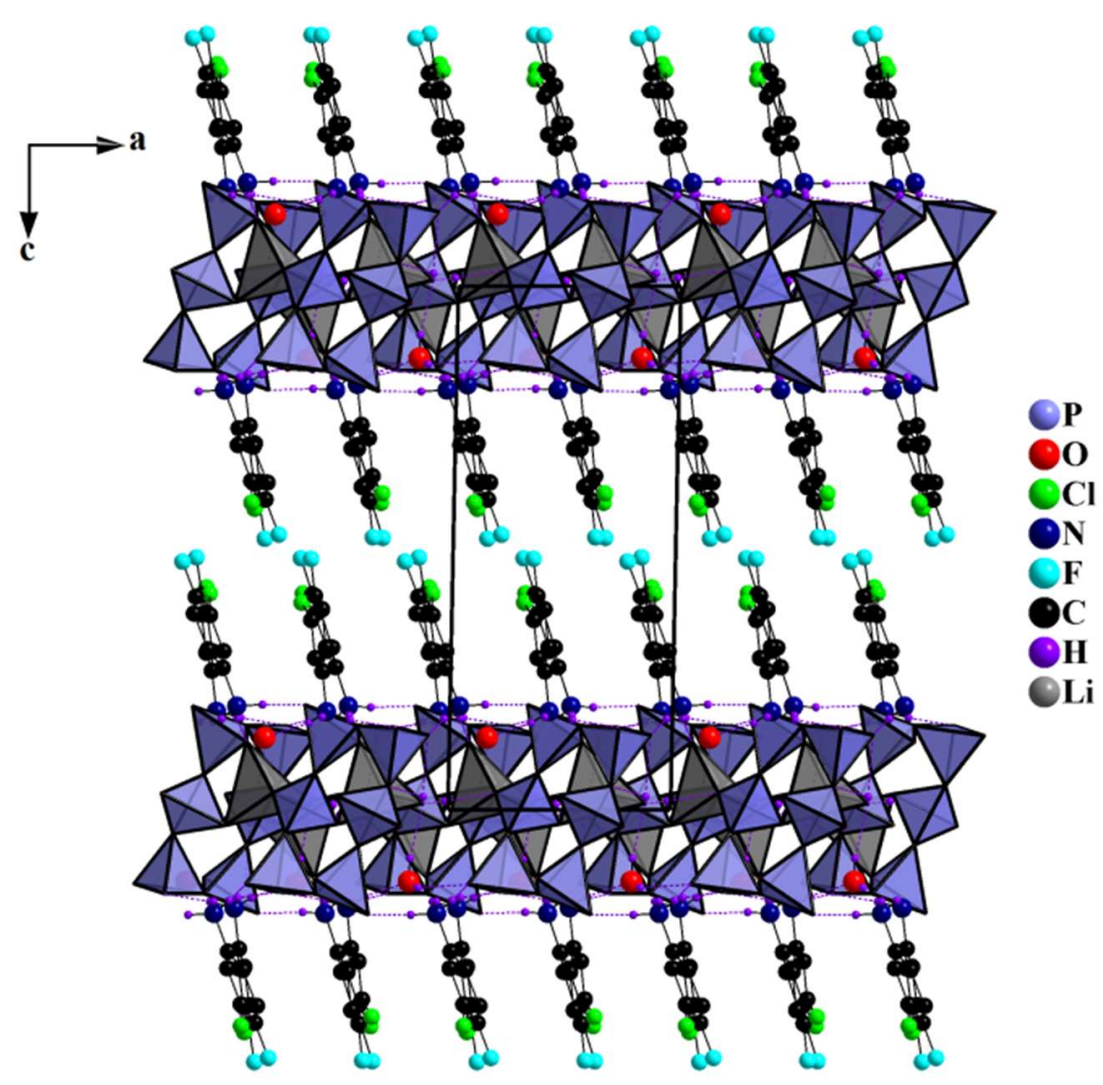


Fig. 3: Atomic arrangement of $\left(\mathrm{C}_{6} \mathrm{H}_{6} \mathrm{ClFN}\right)_{4}(\mathrm{Li})_{2}\left(\mathrm{P}_{6} \mathrm{O}_{18}\right)\left(\mathrm{H}_{2} \mathrm{O}\right)_{4}$, projected along the $b$-axis, showing the linkage between the different entities of the structure

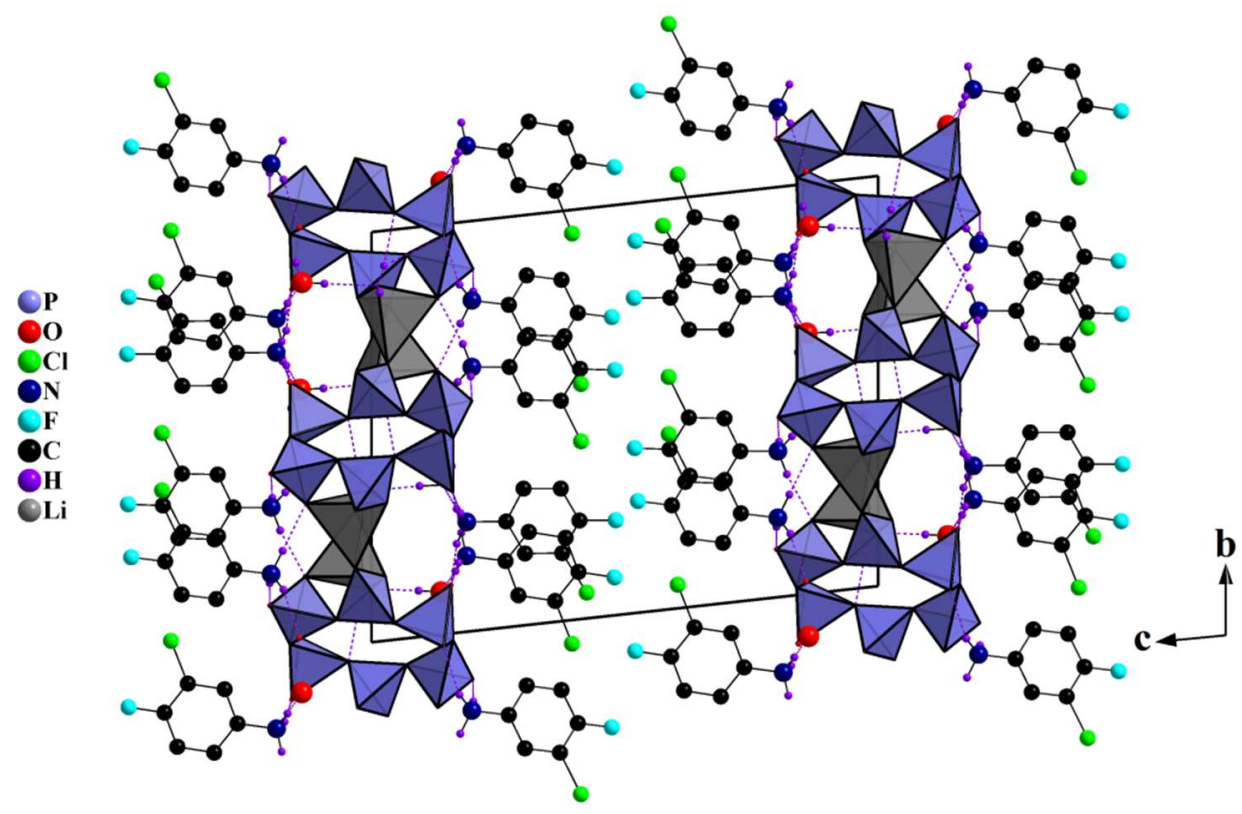

Fig. 4: Atomic arrangement of $\left.\mathrm{C}_{6} \mathrm{H}_{6} \mathrm{ClFN}\right)_{4}(\mathrm{Li})_{2}\left(\mathrm{P}_{6} \mathrm{O}_{18}\right)\left(\mathrm{H}_{2} \mathrm{O}\right)_{4}$ projected along the $\boldsymbol{a}$-axis

The cations are located between these layers and connect them via hydrogen bonds generated by the $-\mathrm{NH}_{3}$ groups, water molecules and some external oxygen atoms of the $\mathrm{P}_{6} \mathrm{O}_{18}$ groups (Fig. 5). In addition, weak C-H...O(E) interactions, listed in Table S2, are observed.

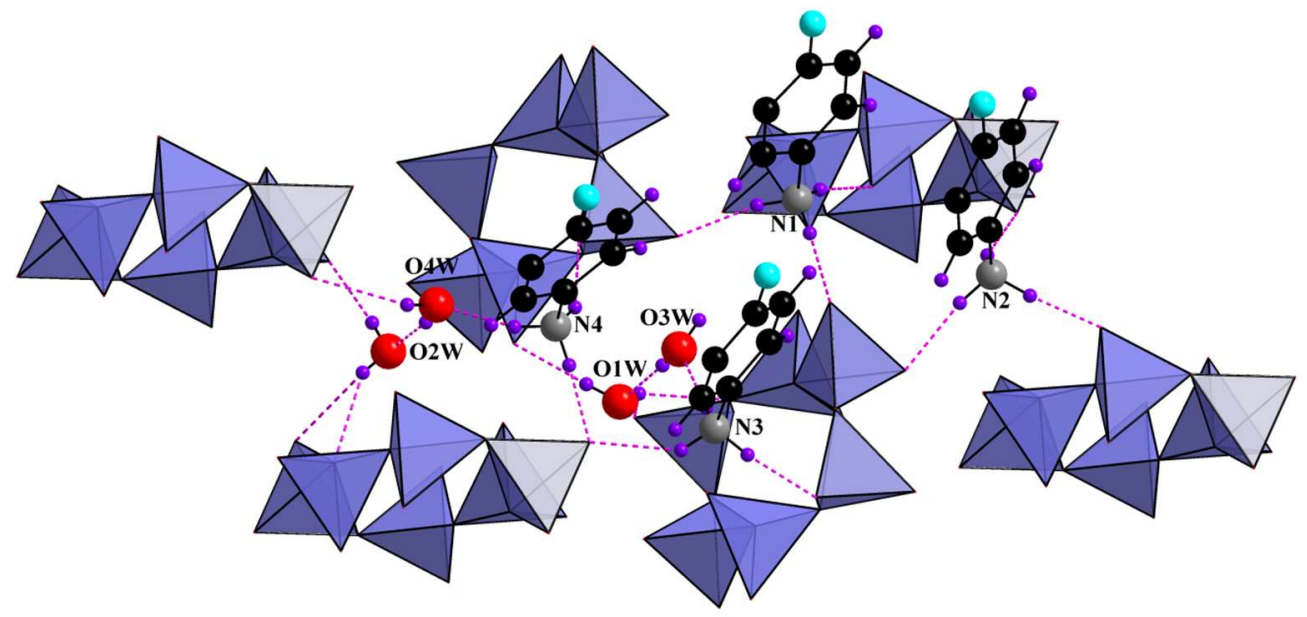

Fig. 5: $\mathrm{H}$-bonds in the crystal structure of $\left(\mathrm{C}_{6} \mathrm{H}_{6} \mathrm{ClFN}\right)_{4}(\mathrm{Li})_{2}\left(\mathrm{P}_{6} \mathrm{O}_{18}\right)\left(\mathrm{H}_{2} \mathrm{O}\right)_{4}$ 
The Li atoms are linked to two water molecules $\mathrm{O}(\mathrm{W})$ and two $\mathrm{O}$ atoms $\mathrm{O}(\mathrm{E})$ belonging to two $\mathrm{P}_{6} \mathrm{O}_{18}{ }^{6-}$ ring anions (Fig. 2). The $\mathrm{LiO}_{4}$ tetrahedron angles appear as regular as the $\mathrm{PO}_{4}$ tetrahedra, but the Li-O distances are slightly distorted ranging from $1.890(4)$ to $2.000(4) \AA$ (Table 2). The smallest distance between two lithium centers is 4.280(2) $\AA$.

\section{Crystal contacts}

In order to analyze interaction propensities in molecular crystals, the contact enrichment applying to the different pairs of chemical species present in the structure was analyzed [29, 30]. An enrichment ratio $E_{\mathrm{XY}}$ larger than unity for a particular contact between chemical species $\mathrm{X} \cdots \mathrm{Y}$ pinpoints that these are over-represented contacts in the crystal packing by comparison with equi-probable contacts. Table 3 shows clearly that the strongly electrostatic attractive $\mathrm{O} \cdots \mathrm{Hn} / \mathrm{o}$ hydrogen bonds $(E=3.5)$ and $\mathrm{O} \ldots \mathrm{Li}$ ionic bridges $(E=3.4)$ are recognized as the most favored contact among all other existing contacts. The O...H-N and O...H-O hydrogen bonds represent actually the main contact surface in the crystal packing at $S=19 \%$.

Table 3. Statistical analysis of intermolecular contacts on the Hirshfeld surface of $\left(\mathrm{C}_{6} \mathrm{H}_{7} \mathrm{ClFN}\right)_{4}$

$(\mathrm{Li})_{2}\left(\mathrm{P}_{6} \mathrm{O}_{18}\right)\left(\mathrm{H}_{2} \mathrm{O}\right)_{4}$

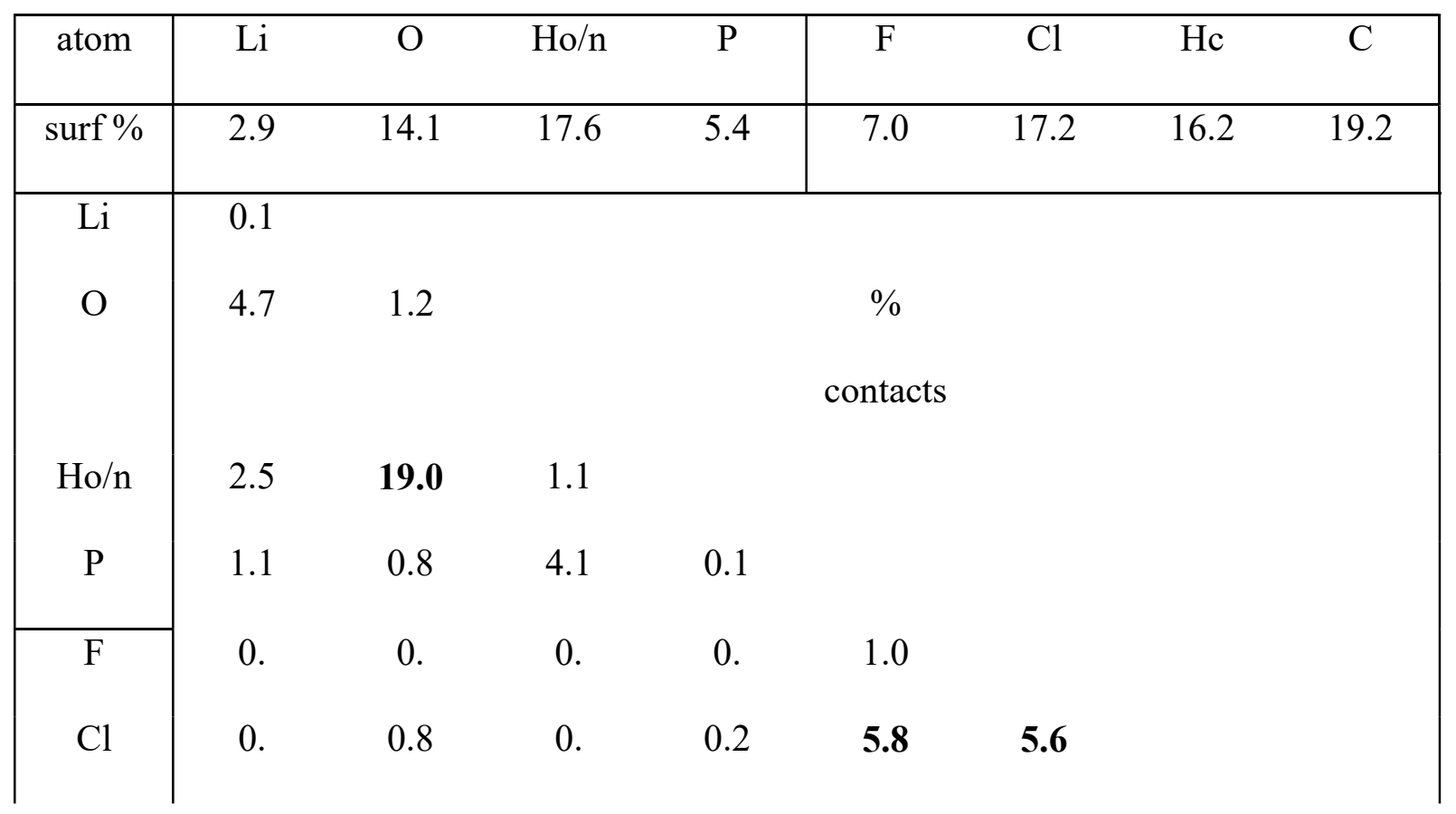




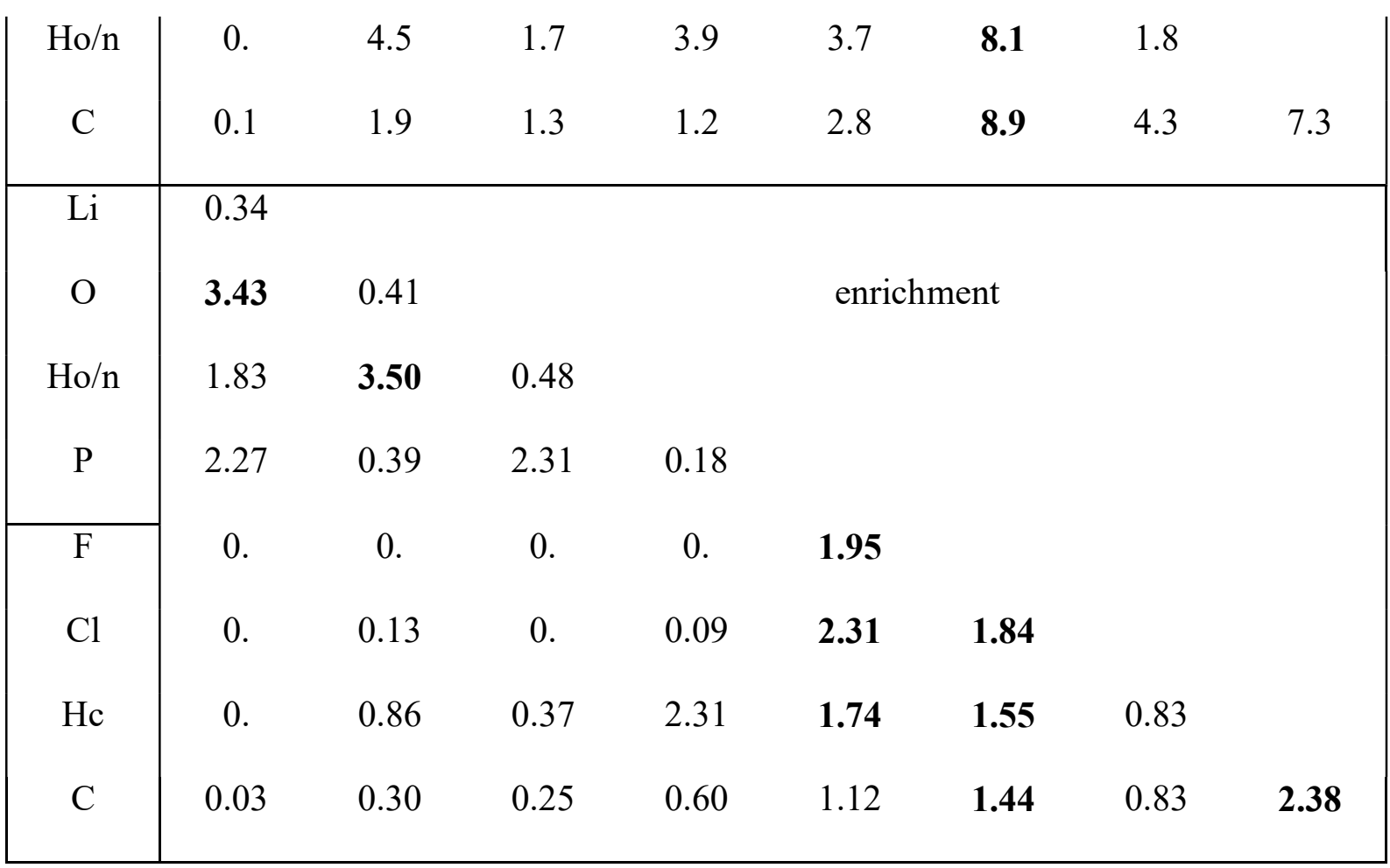

The halogen...halogen contacts $\mathrm{F} \ldots \mathrm{F}, \mathrm{Cl} \ldots \mathrm{Cl}$ and $\mathrm{Cl} \ldots \mathrm{F}$ are all enriched $(E>1.8)$ due to the formation of hydrophobic interaction layers around the planes $z=1 / 2+N$ in the crystal (Figs. 2, 4, 6 and 7). Weak hydrogen bonds $\mathrm{F} . . . \mathrm{Hc}$ and $\mathrm{Cl}$...Hc also occur in the same interaction plane and are similarly enriched $(E=1.7$ and 1.5$)$. On the other hand, O...Hc weak hydrogen bonds between the lowly positively charged $\mathrm{Hc}$ atoms and oxygen atom are disfavored.

All the aromatic cycles have similar orientations and are nearly parallel to the $(a, b)$ plane. Therefore, the extensive occurrence of stacking between halogenated aromatic cycles results in significantly enriched $\mathrm{C} . . \mathrm{C}$ and $\mathrm{Cl}$...C contacts. Among hydrophobic contacts, only Hc...Hc and C...Hc are slightly under-represented. All self-contacts between charged species are impoverished in the crystal system as they concern repulsive self-contacts between charged species. 

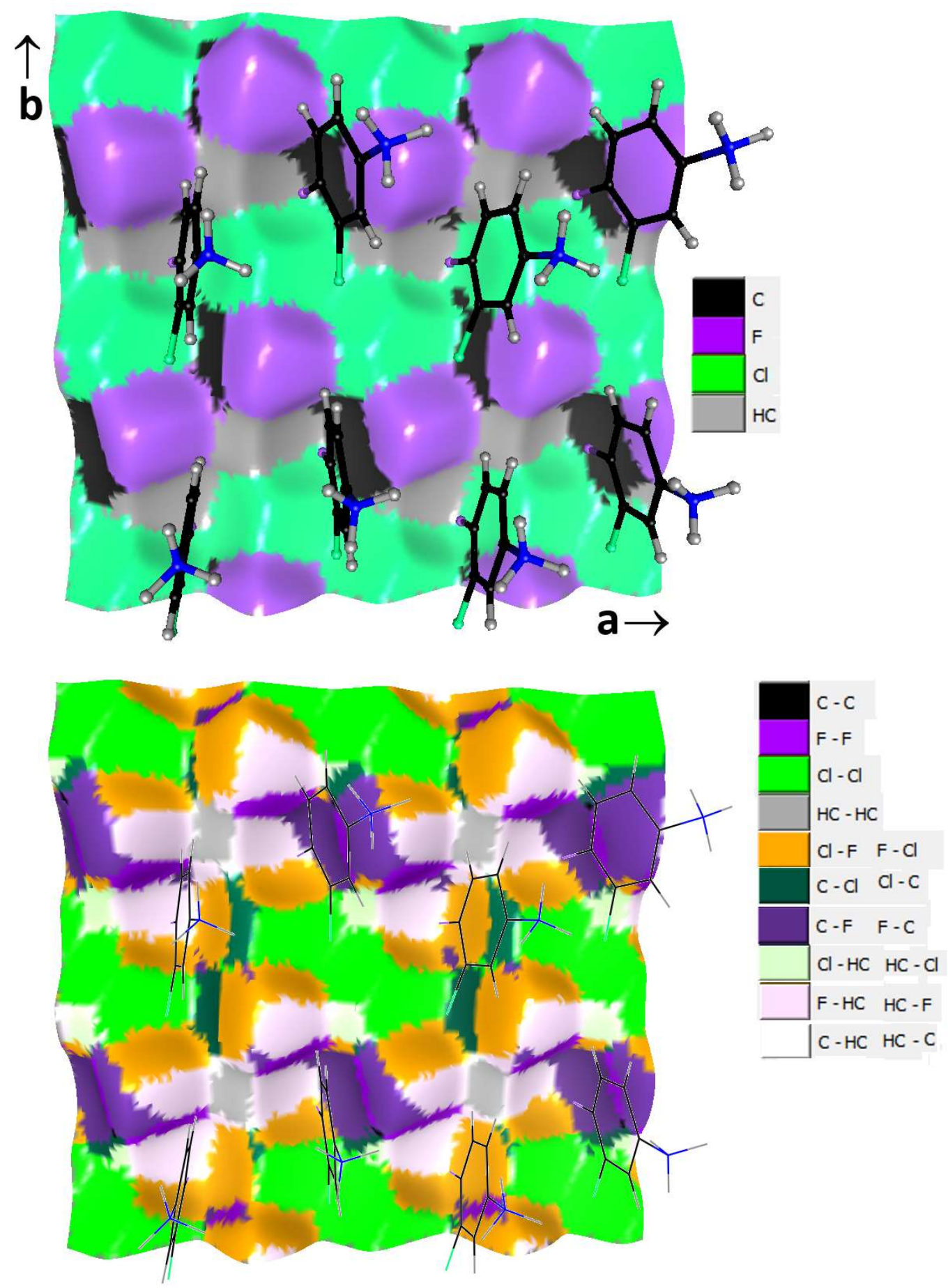

Fig. 6: Autostereogram view of the Hirshfeld surface between two hydrophobic layers around $z=1 / 2$. (a) coloring according to atom type. (b) coloring according to contact type 


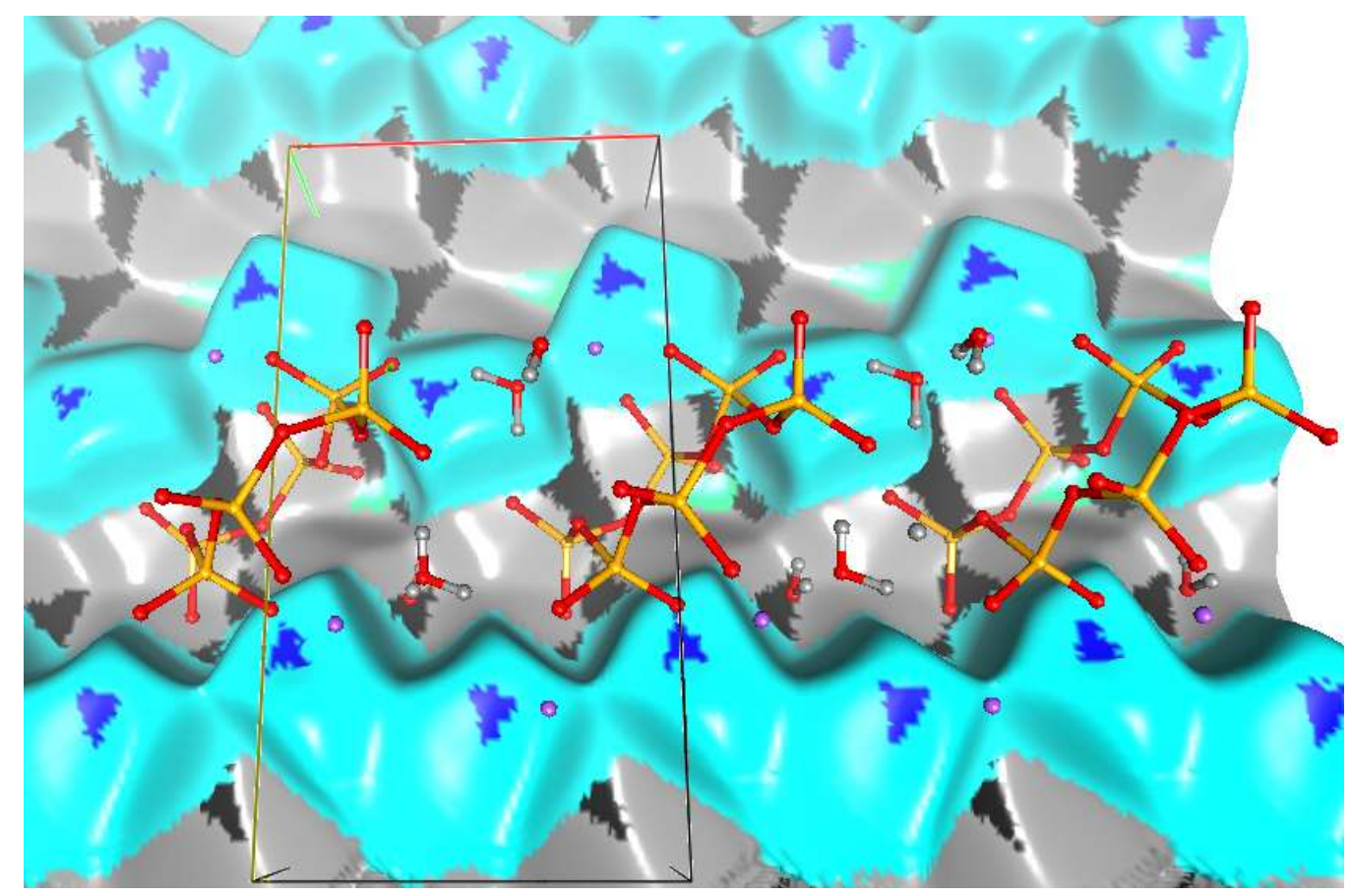

Fig. 7: Crystallographic autostereogram of the Hirshfeld surface between the hydrophilic side of the organic cations $\left(\mathrm{NH}_{3}{ }^{+}\right.$groups) and the hydrophilic layer of cyclohexaphosphate and water molecules. The surface is colored according to the cation atoms, carbon: black, Hc hydrogen: grey, nitrogen: dark blue, Hn nitrogen light blue

Globally, if the $\mathrm{C}, \mathrm{Hc}, \mathrm{F}, \mathrm{Cl}$ atoms are considered hydrophobic, they constitute as much as $60 \%$ of the molecular surface (Table 3). The contacts within this group are over-represented at $E=1.4$, while the enrichment value within the polar (other) chemical types is even higher at 2.2. Conversely the hydrophobic/hydrophilic cross contacts are quite under-represented at $E=0.33$. These statistics reflect the dual nature of the crystal packing with an alternation of hydrophobic and polar layers along the c axis (Fig. 2).

\section{HOMO-LUMO analysis}

The frontier molecular orbitals determine the way of a molecule interacts with other entities and helps to determine its kinetic stability and chemical reactivity. HOMO-LUMO orbitals were calculated for the organic molecule by the DFT-B3LYP / 6-31 + G* Method. The 
calculated HOMO and LUMO orbitals, are calculated by the DFT-B3LYP / 6-31 + G* method for the four crystallographically non-equivalent molecules and are indicated, ligand 1, ligand 2, ligand 3 and ligand 4. In all four cases, identical results were obtained. The highest occupied molecular energy HOMO molecular orbital is located mainly on the aromatic ring and on the chlorine and fluorine atoms with $\mathrm{E}(\mathrm{HOMO})=-11.214 \mathrm{eV}$, while the LUMO lowest energy unoccupied molecular orbital is concentrated on the $\mathrm{NH}_{3}+$ group with $\mathrm{E}(\mathrm{LUMO})=$ energy of $5.519 \mathrm{eV}$. The large energy gap HOMO-LUMO (5.695 eV) indicates high chemical hardness and kinetic stability for the title hybrid material (Fig. 8).

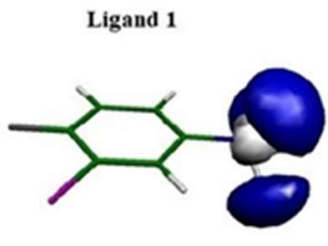

$\mathrm{E}_{\text {LUNeO }}=-\mathbf{5 . 5 6 5 \mathrm { eV }}$

Ligand 3

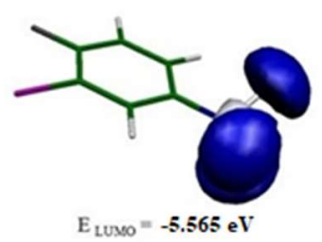

Ligand 1

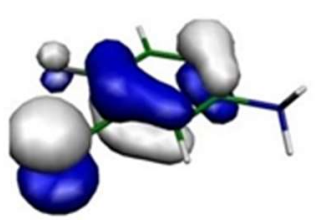

$\mathrm{E}_{\text {Hомо }}=-11.214 \mathrm{eV}$

Ligand 3

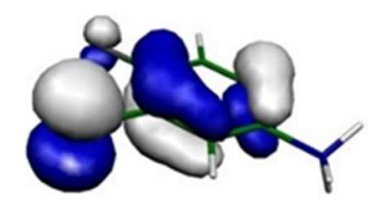

$\mathrm{E}_{\text {BONo }}=-11.280 \mathrm{eV}$

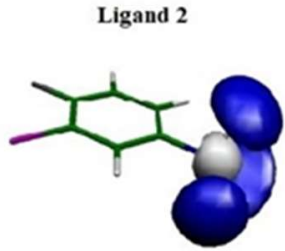

$\mathrm{E}_{\text {LUwo }}=-\mathbf{5 . 5 7 3 \mathrm { eV }}$

Ligand 4

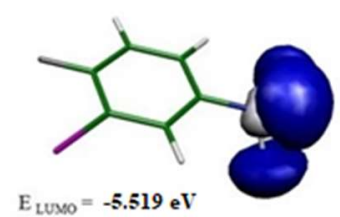

Ligand 2

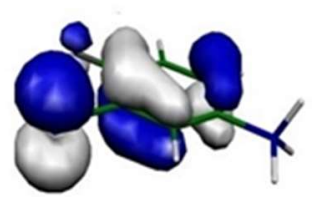

$E_{\text {Hovo }}=-11.186 \mathrm{eV}$

Ligand 4

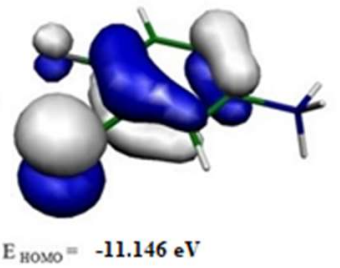

LUMO Orbitals

$E_{g}=5,695 \mathrm{eV}$

HOMO Orbitals

ule in 


\section{Molecular Electrostatic Potential Analysis}

The molecular electrostatic potential of $\left(\mathrm{C}_{6} \mathrm{H}_{7} \mathrm{ClFN}\right)_{4}(\mathrm{Li})_{2}\left(\mathrm{P}_{6} \mathrm{O}_{18}\right)\left(\mathrm{H}_{2} \mathrm{O}\right)_{4}$, computed at the B3LYP/6-31+G* level, and is shown in Fig. 9. As seen from this figure, for cyclohexaphosphate anions, the positive charge (blue color) is localized on the phosphorus, while the negative charge (Red color) is located in the center of the cycle. For the four organic cations, the positive charge is localized on the ammonium group $\mathrm{NH}_{3}{ }^{+}$which can be regarded as electrophilic, whereas the fluorine atom contains the nucleophilic site. These sites are involved in reciprocal intermolecular contacts.
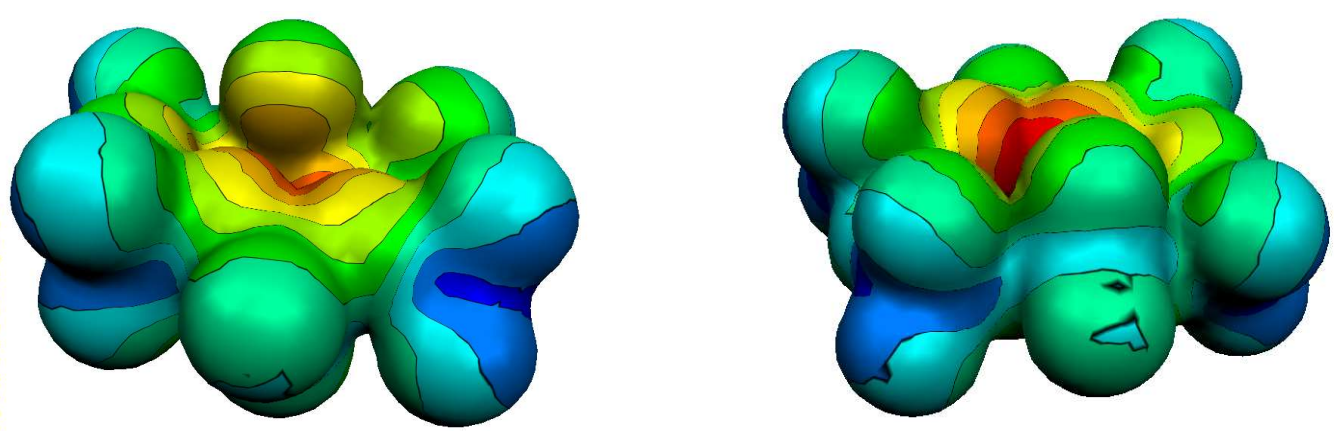

(a)
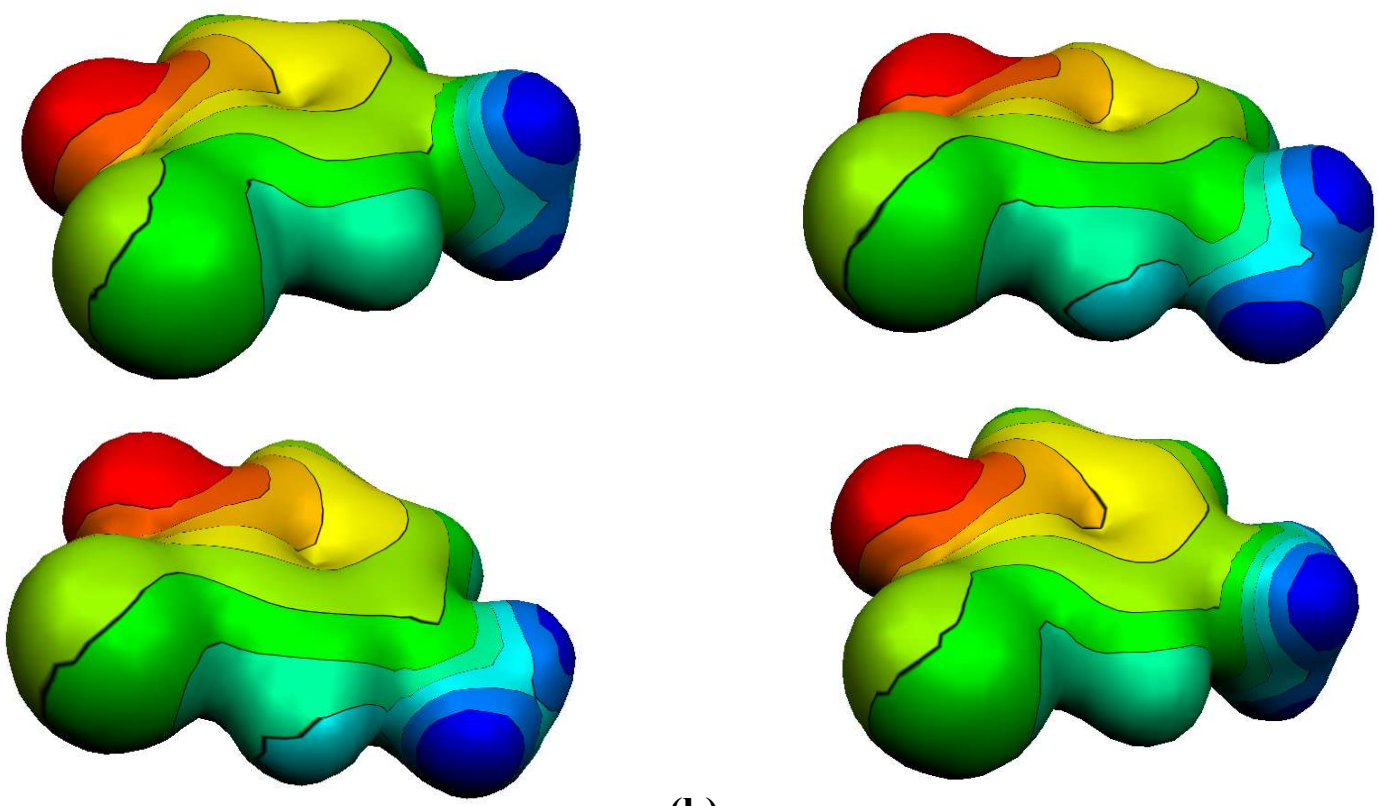

(b)

Fig. 9: Molecular electrostatic potential around the two anions cyclohexaphosphates (a) and the four cations (b) in $\left(\mathrm{C}_{6} \mathrm{H}_{7} \mathrm{ClFN}\right)_{4}(\mathrm{Li})_{2}\left(\mathrm{P}_{6} \mathrm{O}_{18}\right)\left(\mathrm{H}_{2} \mathrm{O}\right)_{4}$ 


\section{NMR results}

The ${ }^{1} \mathrm{H}$ MAS NMR spectrum of the compound $\left(\mathrm{C}_{6} \mathrm{H}_{7} \mathrm{ClFN}\right)_{4}(\mathrm{Li})_{2}\left(\mathrm{P}_{6} \mathrm{O}_{18}\right)\left(\mathrm{H}_{2} \mathrm{O}\right)_{4}$ was recorded with time delays of 1 and 10 seconds (Fig. S1). The two spectra are identical, so that all the CP-MAS spectra were recorded with a delay of one second between two scans so as to be certain that the protons were well relaxed. The spectrum contains an isotropic band at $5 \mathrm{ppm}$, corresponding to the different protons of the compound, and three symmetrical spinning side bands.

The ${ }^{13} \mathrm{C}$ CP-MAS-NMR spectrum of $\left(\mathrm{C}_{6} \mathrm{H}_{6} \mathrm{ClFN}\right)_{4}(\mathrm{Li})_{2} \mathrm{P}_{6} \mathrm{O}_{18} 4 \mathrm{H}_{2} \mathrm{O}$, shown in Fig. 10, exhibits two sets of peaks in the resonance region of the aromatic carbons. Since the large number of possible signals (there are four molecules in the cell), we recorded a spectrum with a very short contact time $(100 \mu \mathrm{s})$ in order to see essentially the carbons bound to protons. Obviously, the signals around $150-160 \mathrm{ppm}$ as well as the peak at $125.9 \mathrm{ppm}$ correspond to carbons that are not directly bound to protons.

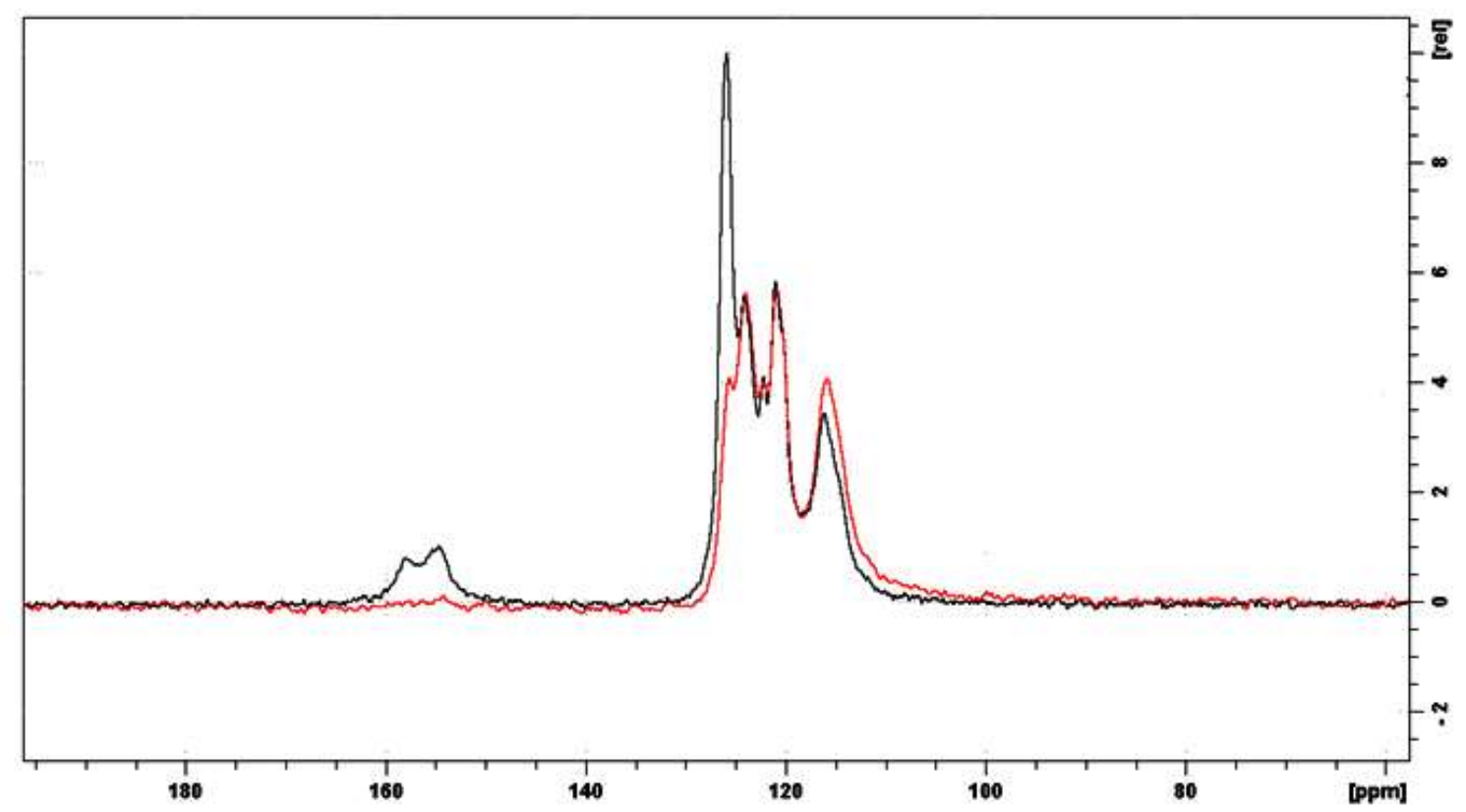


Fig. 10: ${ }^{13} \mathrm{C}$ CP-MAS NMR Spectrum of $\left(\mathrm{C}_{6} \mathrm{H}_{7} \mathrm{ClFN}\right)_{4}(\mathrm{Li})_{2}\left(\mathrm{P}_{6} \mathrm{O}_{18}\right)\left(\mathrm{H}_{2} \mathrm{O}\right)_{4}$ recorded at a contact time of $2 \mathrm{~ms}$ in black and $100 \mu \mathrm{s}$ in red.

The 2D HETCOR carbon-proton spectrum is given in Fig. 11. It shows that all proton resonances occur at the same zone of chemical shifts.

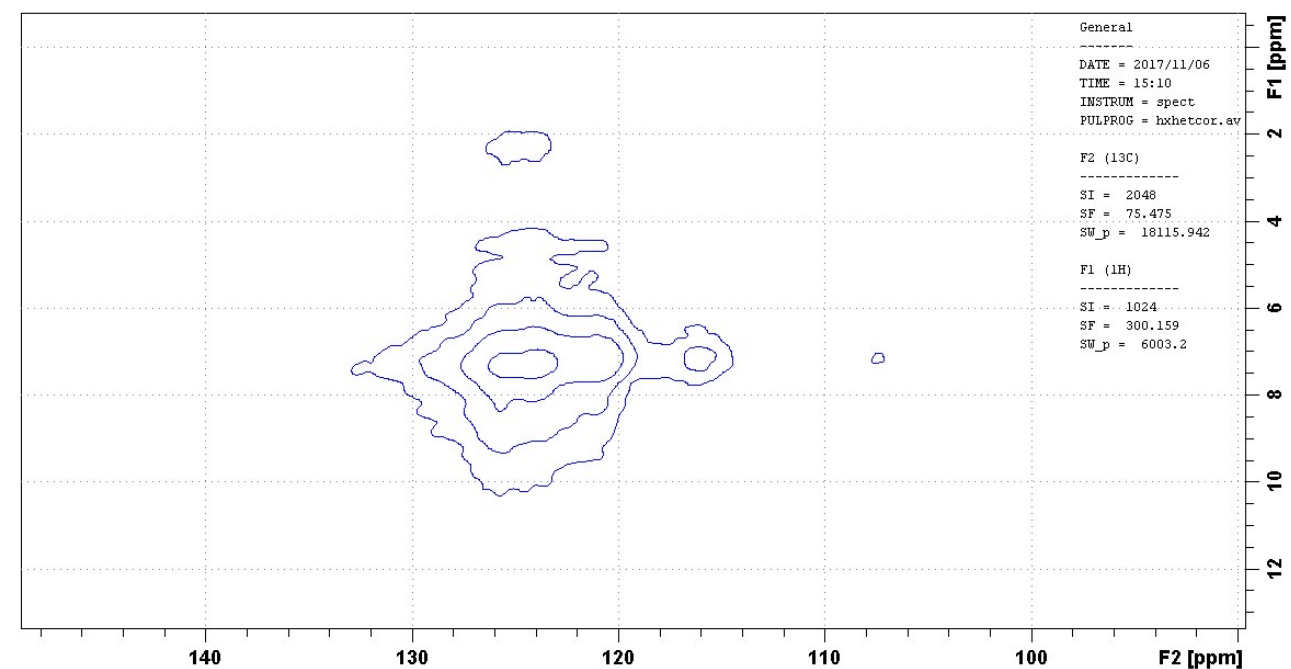

Fig. 11: ${ }^{1} \mathrm{H} /{ }^{13} \mathrm{C}$ HETCOR 2D NMR Spectrum of $\left(\mathrm{C}_{6} \mathrm{H}_{6} \mathrm{ClFN}\right)_{4}(\mathrm{Li})_{2} \mathrm{P}_{6} \mathrm{O}_{18} .4 \mathrm{H}_{2} \mathrm{O}$

The solid state ${ }^{31} \mathrm{P}$ spectrum of the sample is formed by six components (Fig. 12) corresponding to the six crystallographically independent phosphorus atoms, as revealed by the crystallographic study.

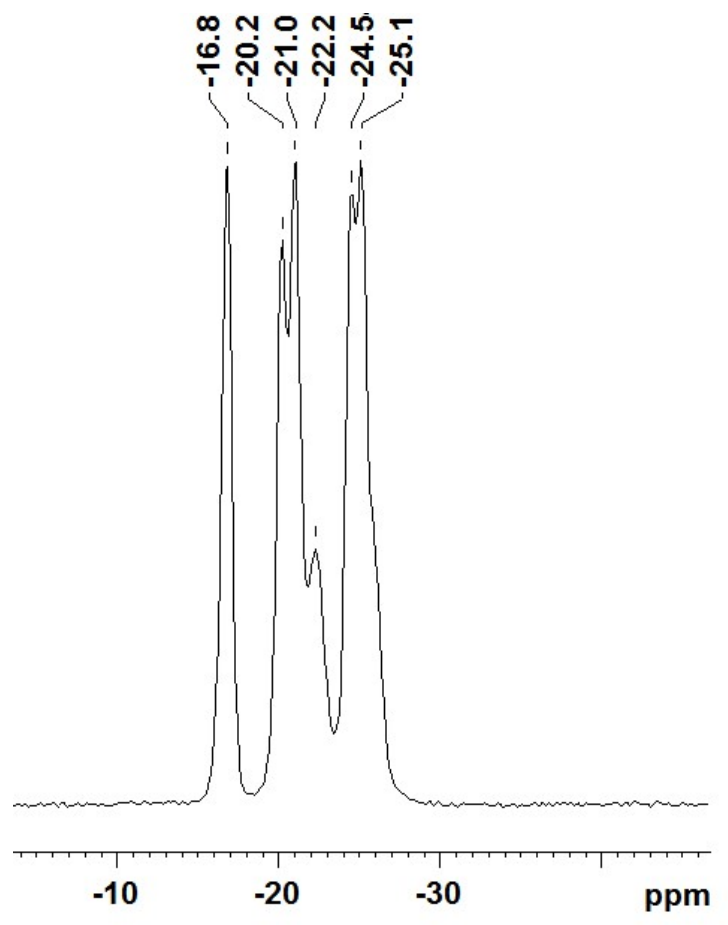


Fig. 12: ${ }^{31} \mathrm{P}$ CP-MAS NMR spectrum of $\left(\mathrm{C}_{6} \mathrm{H}_{7} \mathrm{ClFN}\right)_{4}(\mathrm{Li})_{2}\left(\mathrm{P}_{6} \mathrm{O}_{18}\right)\left(\mathrm{H}_{2} \mathrm{O}\right)_{4}$.

Fig. 13 illustrates the ${ }^{15} \mathrm{~N}$ NMR spectrum CP-MAS of $\left(\mathrm{C}_{6} \mathrm{H}_{7} \mathrm{ClFN}\right)_{4}(\mathrm{Li})_{2}\left(\mathrm{P}_{6} \mathrm{O}_{18}\right)\left(\mathrm{H}_{2} \mathrm{O}\right)_{4}$. It exhibits three peaks corresponding to the four nitrogens of the asymmetric unit with the one at $-357 \mathrm{ppm}$ broader than the other two and corresponding to two different nitrogen atoms.

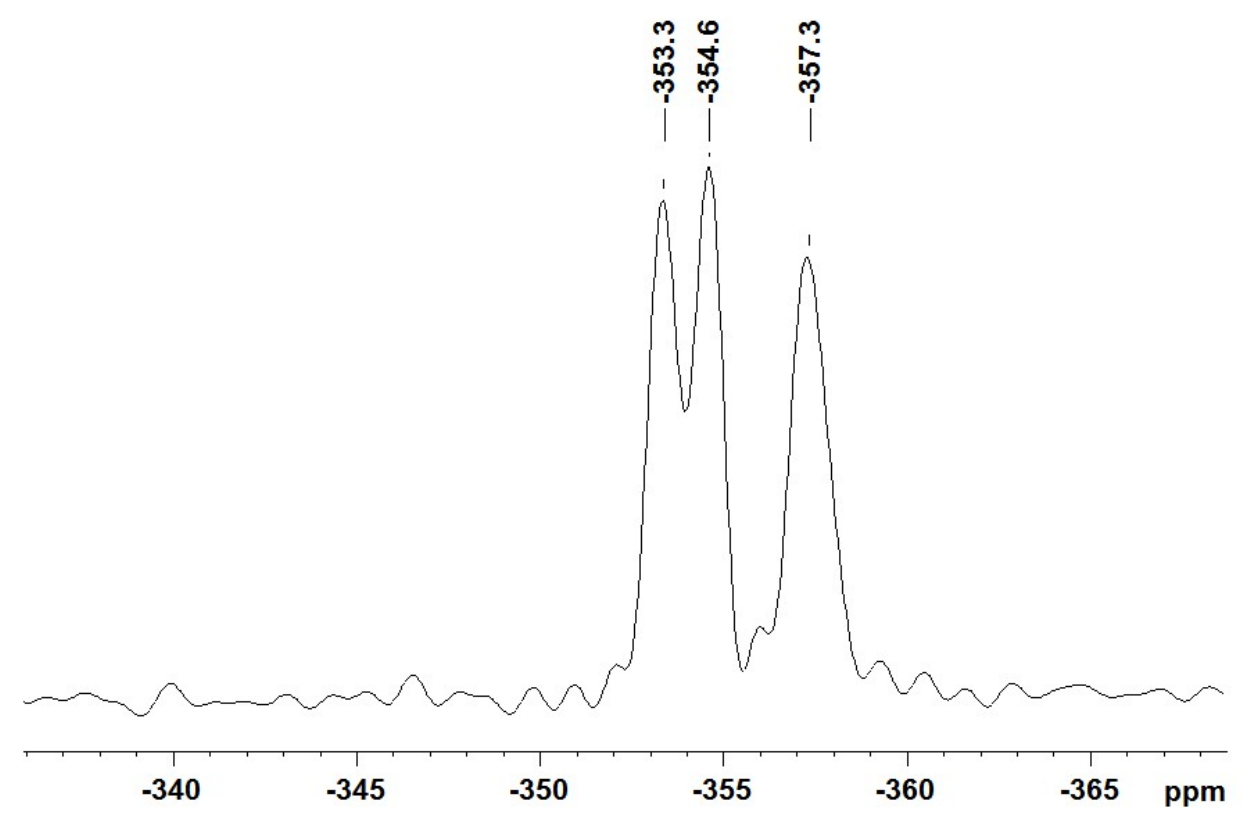

Fig. 13: ${ }^{15} \mathrm{~N}$ CP-MAS NMR spectrum of $\left(\mathrm{C}_{6} \mathrm{H}_{6} \mathrm{ClFN}\right)_{4}(\mathrm{Li})_{2} \mathrm{P}_{6} \mathrm{O}_{18} .4 \mathrm{H}_{2} \mathrm{O}$.

Fig. 14 shows the ${ }^{19} \mathrm{~F}$ MAS-NMR spectrum of $\left(\mathrm{C}_{6} \mathrm{H}_{7} \mathrm{ClFN}\right)_{4}(\mathrm{Li})_{2}\left(\mathrm{P}_{6} \mathrm{O}_{18}\right)\left(\mathrm{H}_{2} \mathrm{O}\right)_{4}$ recorded with two rotation speeds $(10.000$ and $12.000 \mathrm{~Hz})$ to determine the position of the central (or isotropic) bands. Obviously, these bands whose positions do not depend on the speed of rotation are localized between -110 and $-115 \mathrm{ppm}$. The presence of four isotropic bands proves that the compound contains four organic entities in the asymmetric unit, in perfect agreement with the results of single crystal X-ray diffraction. 

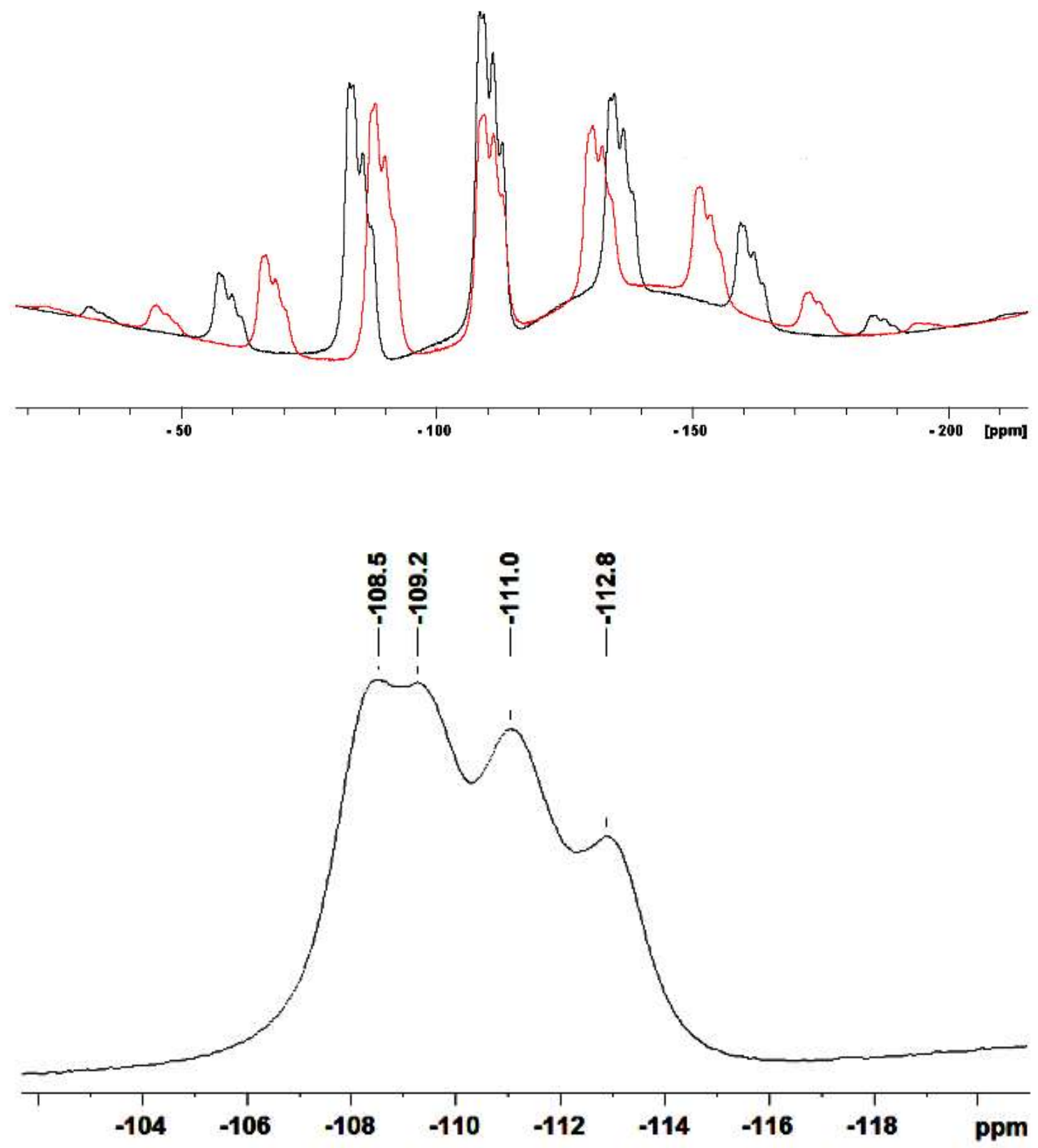

Fig. 14: ${ }^{19} \mathrm{~F}$ CP-MAS NMR spectrum of $\left(\mathrm{C}_{6} \mathrm{H}_{6} \mathrm{ClFN}\right)_{4}(\mathrm{Li})_{2} \mathrm{P}_{6} \mathrm{O}_{18} .4 \mathrm{H}_{2} \mathrm{O}$ recorded at a rotation speed of 10,000 Hz (in red) and 12,000 Hz (in black).

Theoretical calculations with Gaussian 09 were made for the four molecules of the asymmetric unit, to assign the NMR components, with first optimization of proton positions and calculation of chemical shifts by the GIAO method. In all cases the functional was B3LYP and the base $6-31+\mathrm{G} *$ for all atoms. The chemical shifts of carbon are relative values taking 
as reference the TMS calculated under the same conditions. The values for nitrogen and fluorine are absolute values. The numbering of atoms is as follows:

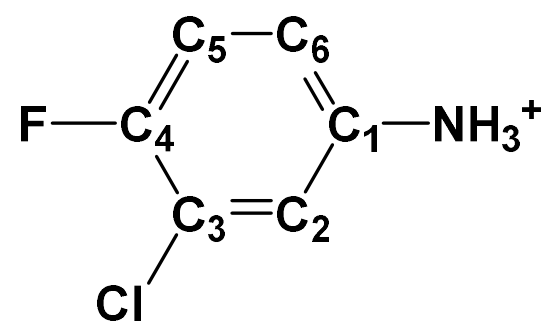

Table 4, gathering the obtained results, shows that there is a good agreement between the experimental and theoretical values leading unambiguously to attribute the different signals. The difference between the experimental and theoretical values of the chemical shifts is due to the fact that the spectrum has been recorded in the solid state, whereas the theoretical chemical shift corresponds to the isolated molecule of the compound. It should be noted that we find the positions of carbon atoms $\mathrm{C} 3$ and $\mathrm{C} 4$ not bound to protons and the $\mathrm{C}-\mathrm{F}$ coupling.

Table 4. Chemical shift values (ppm) of carbon atoms of $\left(\mathrm{C}_{6} \mathrm{H}_{7} \mathrm{ClFN}\right)_{4}(\mathrm{Li})_{2}\left(\mathrm{P}_{6} \mathrm{O}_{18}\right)\left(\mathrm{H}_{2} \mathrm{O}\right)_{4}$ organic groups.

\begin{tabular}{|c|c|c|c|c|c|c|}
\hline Atoms & $\begin{array}{c}\text { Ligand 1 } \\
(\mathrm{ppm})\end{array}$ & $\begin{array}{c}\text { Ligand 2 } \\
(\mathrm{ppm})\end{array}$ & $\begin{array}{c}\text { Ligand 3 } \\
(\mathrm{ppm})\end{array}$ & $\begin{array}{c}\text { Ligand 4 } \\
(\mathrm{ppm})\end{array}$ & optimization & $\begin{array}{c}\text { Full } \\
(\mathrm{ppm})\end{array}$ \\
\hline $\mathrm{C} 1$ & 107.4 & 108.5 & 108.1 & 108.5 & 114.0 & 116.1 \\
\hline $\mathrm{C} 2$ & 115.0 & 115.5 & 115.8 & 115.2 & 118.2 & $120-124$ \\
\hline $\mathrm{C} 3$ & 128.6 & 130.3 & 128.7 & 130.9 & 135.4 & 125.9 \\
\hline $\mathrm{C} 4$ & 154.8 & 154.4 & 155.4 & 155.7 & 159.8 & 154.7 \\
\hline C5 & 114.3 & 114.5 & 114.6 & 113.6 & 117.9 & $120-124$ \\
\hline C6 & 111.7 & 112.8 & 111.8 & 112.7 & 115.4 & $120-124$ \\
\hline
\end{tabular}




\section{Vibrational analysis}

Fig. S2 shows the IR spectrum of $\left(\mathrm{C}_{6} \mathrm{H}_{6} \mathrm{ClFN}\right)_{4}(\mathrm{Li})_{2}\left(\mathrm{P}_{6} \mathrm{O}_{18}\right)\left(\mathrm{H}_{2} \mathrm{O}\right)_{4}$. It exhibits the bands corresponding to vibrations of $\left(\mathrm{P}_{6} \mathrm{O}_{18}\right)^{6-}$ anion, water molecules and 3-chloro-4-fluoroanilinuim cation.

To assign the observed IR peaks to vibrational modes, we have examined previous works reported in similar cyclohexaphosphates [26-28].

For the inorganic part, characteristic bands at 1249 and $1122 \mathrm{~cm}^{-1}$ are attributed to asymmetric and symmetric stretching vibrations of OPO groups, while those at 968 and 764 $\mathrm{cm}^{-1}$ are assigned to $v_{\mathrm{as}}(\mathrm{POP})$ and $v_{\mathrm{s}}(\mathrm{POP})$ groups, respectively.

The broad bands in the range $3500-2300 \mathrm{~cm}^{-1}$ correspond to the stretching vibrations of the organic and hydroxyl groups $v(\mathrm{~N}-\mathrm{H}), v(\mathrm{C}-\mathrm{H})$ and $v(\mathrm{O}-\mathrm{H})$.

The vibrations around $1645 \mathrm{~cm}^{-1}$ are assigned to in-plane $\mathrm{OH}$ and $\mathrm{N}-\mathrm{H}$ deformations $(\delta(\mathrm{O}-\mathrm{H})$ and $\delta(\mathrm{N}-\mathrm{H}))$. The band at $1498 \mathrm{~cm}^{-1}$ corresponds to $v(\mathrm{C}=\mathrm{C})_{\mathrm{Ar}}$ stretching vibrations. The C-C stretching vibrations of aromatic groups usually occur as associated with other bands below $1650 \mathrm{~cm}^{-1}$. Bending, translation and rotation of the $\mathrm{P}_{6} \mathrm{O}_{18}$ anion, $\mathrm{C}-\mathrm{C}$ bending and $\mathrm{NH}_{3}$ torsion may occur in the region below $660 \mathrm{~cm}^{-1}$.

\section{Electrical characterization}

AC impedance spectroscopy is widely employed to obtain information related to the electrical behavior of materials. The impedance diagrams measured at different temperatures under air for the chromium compound pellet and the equivalent circuit is illustrated in Fig.15a. The data of the impedance spectra (IS) was fitted to the equivalent circuit of the $\mathrm{R}_{\mathrm{s}}(\mathrm{R} C P E)$ shown in Fig. 15-b, where $R_{s}$ is the ohmic resistance of the compound, $R$ is resistance and CPE is a constant phase element representing time-dependent capacitive elements. The component 
( $\mathrm{R}, \mathrm{CPE}$ ), appears as a semi-circle in the high and medium -frequency region. The amplitude of this arc is thermally dependent.

For a pellet with thickness, $\mathrm{L}$, and section area, $\mathrm{d}$, the total conductivity was calculated using the following relation: $\sigma=1 / \mathbf{R}_{\mathbf{R}} \times \mathbf{L} / \mathbf{d}$

Where $\mathrm{R}$ is the resistance obtained from impedance spectra.

The observed conductivity of this compound was varied between $1.707 \times 10^{-4} \mathrm{Scm}^{-1}$ and $96.5 \times 10^{-4} \mathrm{Scm}^{-1}$ (Table 5) which was higher than that found for the lithium gadolinium polyphosphate [31] and also higher than what has been reported in the literature $[32,33]$. Indeed, this value is larger than what has previously been found for similar organic cyclohexaphosphate [34].

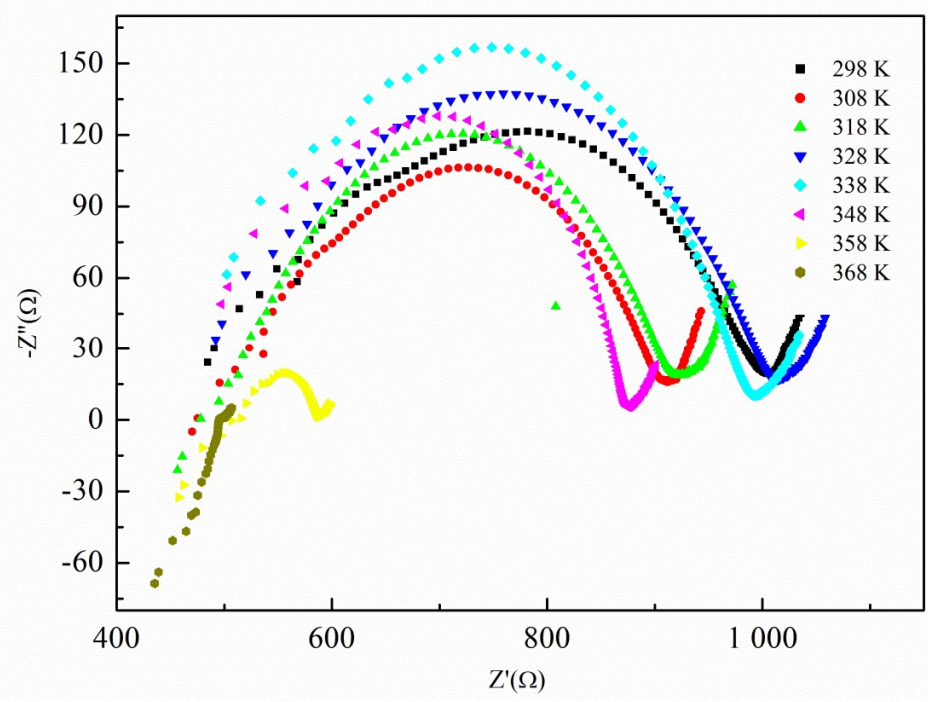

(a)

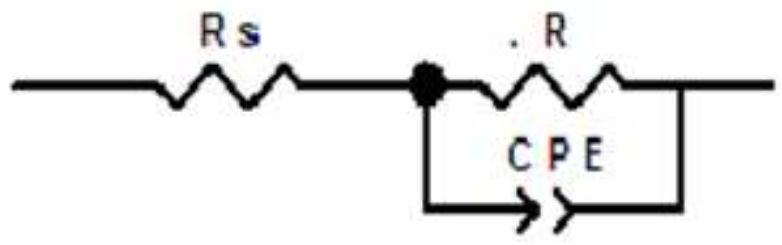

(b) 
Fig. 15: a) Complex plane impedance plots at different temperatures, b) equivalent circuit used for fitting

Table 5. Conductivity value at different temperatures.

\begin{tabular}{|l|l|}
\hline Temperature/ K & Conductivity $/ 10^{-4} \mathrm{Scm}^{-1}$ \\
\hline 298 & 1.746 \\
\hline 308 & 2.237 \\
\hline 318 & 2.138 \\
\hline 328 & 1.707 \\
\hline 338 & 1.755 \\
\hline 348 & 2.495 \\
\hline 358 & 4.312 \\
\hline 368 & 12.50 \\
\hline 378 & 96.5 \\
\hline
\end{tabular}

\section{In Vitro Antioxidant Activity}

The antioxidant activity of $\left(\mathrm{C}_{6} \mathrm{H}_{6} \mathrm{ClFN}\right)_{4}(\mathrm{Li})_{2}\left(\mathrm{P}_{6} \mathrm{O}_{18}\right)\left(\mathrm{H}_{2} \mathrm{O}\right)_{4}$ was evaluated, in vitro, using 1,1-diphenyl-2-picrylhydrazyl (DPPH), ferric reducing power (FRAP) and Trolox equivalent antioxidant capacity (TEAC) methods using 6-hydroxy-2,5,7,8tetramethylchroman-2-carboxylic acid (Trolox) as a standard. The results are interpreted in Figs. S3, S4, 16 and 17, respectively. The synthesized compound exhibited appreciable antioxidant activity

\section{DPPH Free Radical Scavenging Activity}

The antioxidant activity of $\left(\mathrm{C}_{6} \mathrm{H}_{6} \mathrm{ClFN}\right)_{4}(\mathrm{Li})_{2}\left(\mathrm{P}_{6} \mathrm{O}_{18}\right)\left(\mathrm{H}_{2} \mathrm{O}\right)_{4}$ was assessed by its ability to scavenge DPPH using a modified literature method [35]. The studied compound was screened for its DPPH free radical scavenging activity in the concentration range $0.5-3 \mathrm{mg} \cdot \mathrm{mL}^{-}$ 
${ }^{1}$. It showed significant scavenging effects with increasing concentration from 0.5 to $3 \mathrm{mg} . \mathrm{mL}^{-}$ 1, as shown in Fig. S3. The tests of $\left(\mathrm{C}_{6} \mathrm{H}_{6} \mathrm{ClFN}\right)_{4}(\mathrm{Li})_{2}\left(\mathrm{P}_{6} \mathrm{O}_{18}\right)\left(\mathrm{H}_{2} \mathrm{O}\right)_{4}$ against DPPH ${ }^{*}$ show that this phosphate has an important ability to scavenge these free radicals. The values of inhibition percentages of the synthesized material, at different concentrations, with a half-maximal inhibitory concentration $\left(\mathrm{IC}_{50}\right)$ of $1.75 \pm 0.8 \mathrm{mg} \cdot \mathrm{mL}^{-1}\left(\mathrm{IC}_{50}=45.62 \mu \mathrm{M}\right.$ for trolox as illustrated in Fig. S4) show a trolox equivalent antioxidant capacity (TEAC) of 26.081.

\section{ABTS free radical scavenging assay}

The ABTS ability was determined according to the method described by Roberta et al. [36]. Fig. 16 reports the results of ABTS free radical scavenging of $\left(\mathrm{C}_{6} \mathrm{H}_{6} \mathrm{ClFN}\right)_{4}(\mathrm{Li})_{2}\left(\mathrm{P}_{6} \mathrm{O}_{18}\right)\left(\mathrm{H}_{2} \mathrm{O}\right)_{4}$ at different concentrations $\left(2-12 \mathrm{mg}^{-\mathrm{mL}^{-1}}\right)$. It was found that the highest ABTS ability is at $\left.12 \mathrm{mg} \cdot \mathrm{mL}^{-1}\right) ; \%$ Inhibition= 57.67 with $\mathrm{IC}_{50}=8.83 \pm 0.05 \mathrm{mg} \cdot \mathrm{mL}^{-}$ ${ }^{1}\left(\mathrm{IC}_{50}=221.02 \mu \mathrm{M}\right.$ for trolox as shown in Fig. 17). The Trolox equivalent antioxidant capacity (TEAC) is 25.03 .

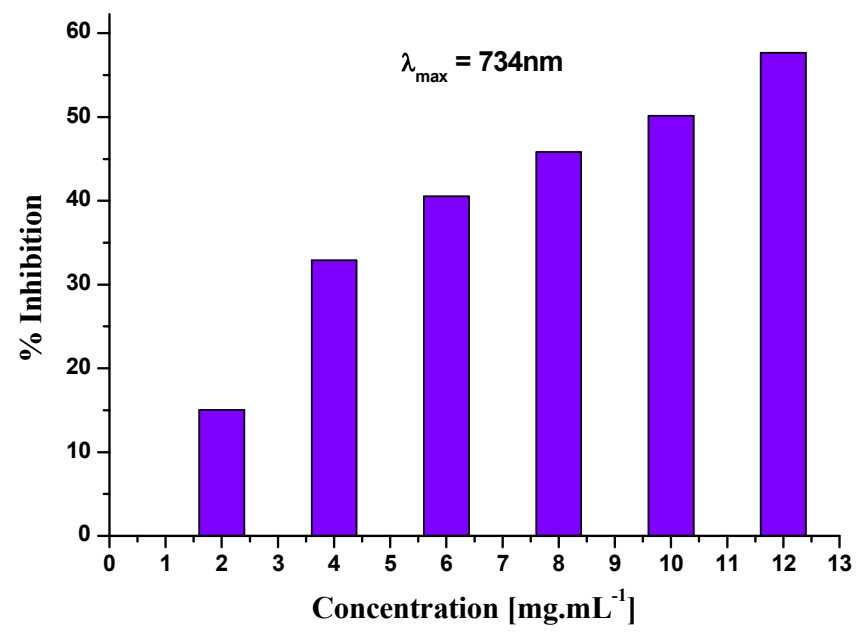

Fig. 16: ABTS radical scavenging activity at different concentrations of

$$
\left(\mathrm{C}_{6} \mathrm{H}_{7} \mathrm{ClFN}\right)_{4}(\mathrm{Li})_{2}\left(\mathrm{P}_{6} \mathrm{O}_{18}\right)\left(\mathrm{H}_{2} \mathrm{O}\right)_{4}
$$




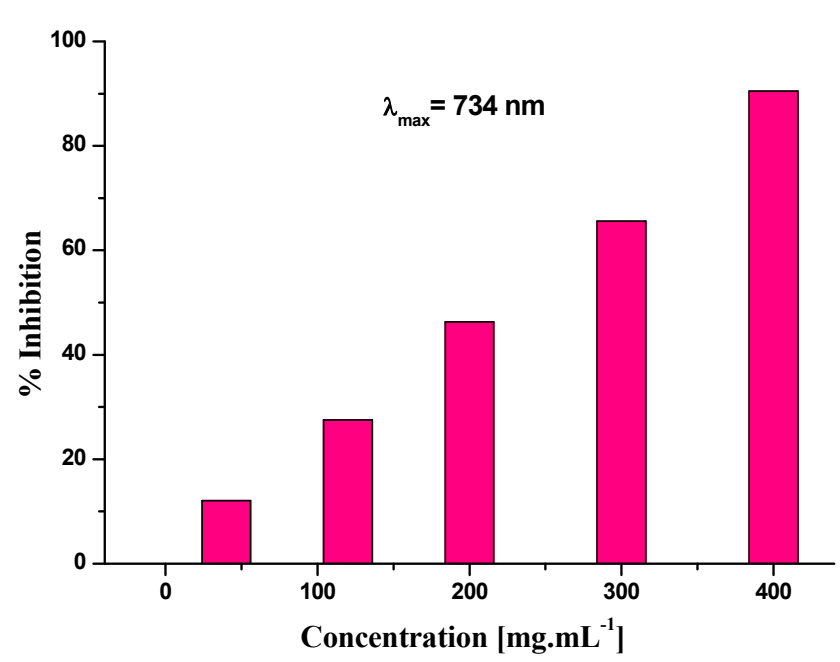

Fig. 17: ABTS radical scavenging activity at different concentrations of trolox

\section{Ferric reducing power (FRAP)}

Reducing power was measured according to the method described by Binsan and al. [37]. The Trolox equivalent antioxidant capacity (TEAC) is $49.79 \pm 6.5$

\section{Conclusion}

A new organic cation cyclohexaphosphate $\left(\mathrm{C}_{6} \mathrm{H}_{6} \mathrm{ClFN}\right)_{4}(\mathrm{Li})_{2}\left(\mathrm{P}_{6} \mathrm{O}_{18}\right)\left(\mathrm{H}_{2} \mathrm{O}\right)_{4}$ was synthesized at room temperature. Its crystal structure is built by two hybrid layers: the first one, developed parallel to the $(\mathbf{a}, \mathbf{b})$ plane around $z=0$, is made of inorganic $\left[\mathrm{Li}_{2} \mathrm{P}_{6} \mathrm{O}_{18} \cdot \mathrm{H}_{2} \mathrm{O}\right]^{4-}$ entities. The second one, sandwiched in the space between the inorganic layers, is built by organic $\left[\mathrm{C}_{6} \mathrm{H}_{6} \mathrm{ClFN}\right]^{+}$cations. The organic components perform interactions of different natures (H-bonds, electrostatic, Van der Waals) to stabilize the three-dimensional network. The crystal packing is dual, as it is maintained by strong polar interactions $\left(\mathrm{O} \ldots \mathrm{H}-\mathrm{N}, \mathrm{O} \ldots \mathrm{H}-\mathrm{O}, \mathrm{O} \ldots \mathrm{Li}^{+}\right)$in planes around $z=N$, and by hydrophobic interactions in layers around $z=1 / 2+N$. The numbers of NMR components agree with the crystallographic data. The obtained electrochemical results show that the new $\left(\mathrm{C}_{6} \mathrm{H}_{6} \mathrm{ClFN}\right)_{4}(\mathrm{Li})_{2}\left(\mathrm{P}_{6} \mathrm{O}_{18}\right)\left(\mathrm{H}_{2} \mathrm{O}\right)_{4}$ organic cyclohexaphosphate may be useful in a great variety of devices such as batteries, super-capacitors and gas sensors.

\section{Supplementary data}


Supplementary crystallographic data for this article in CIF format are available at the Electronic Supplementary Publication from Cambridge Crystallographic Data Centre (CCDC 1913350). This data can be obtained free of charge via http://www.ccdc.cam.ac.uk/conts/retrieving.html, from the Cambridge Crystallographic Data Centre, 12 Union Rood, Cambridge CB2 1EZ, UK (Fax: (international): +44 1223/336 033; email: deposit@ ccdc.cam.ac.uk).

\section{References}

1. R. A. Hearn, C. E. Bugg Acta Cryst. B28, 3662 (1972)

2. J. M. Adams, Acta Cryst. B33, 1513 (1977)

3. L. Baouab, A. Jouini J. Solid State Chem. 141, 343 (1998)

4. M.T. Averbuch-Pouchot, A. Durif, J.C. Guitel, Acta Cryst. C44, 99 (1988)

5. M.T. Averbuch-Pouchot, A. Durif, J.C. Guitel, Acta Cryst. C45, 421 (1989)

6. M. Wojtas, G. Bator, R. Jakubas and J. Zaleski, J. Phys. Condens. Matter 15, 5765 (2003)

7. N. N. Chudinova, E. V. Murashova, B. S Zakharova, Zh. Neorg. Khim. 43, 885 (1998)

8. Lazernye Fosfatnye Stekla (1980). In Laser Phosphate Glasses, Zhabotinskii M E (ed) (Moscow: Nauka)

9. I. Ameur, S. Abid, S. S. Al-Deyab, M. Rzaigui, Acta Cryst. E69, m305 (2013)

10. R. Bel Haj Salah, L. Khedhiri, M. Rzaigui, X-Ray Struct. Anal. Online. 26, 45 (2010)

11. L. Khedhiri, X-Ray Struct. Anal. Online. 20, x143 (2004)

12. O. Amri, S. Abid, M. Rzaigui, Phosphorus Sulfur Silicon Relat. Elem. 184, 766 (2009) 
13. L. Khedhiri, V. Ferretti, C. Jelsch, M. Rzaigui, C. Ben Nasr, J. Mol. Struct. 1134, $828(2017)$

14. A. Hamdi, L. Khedhiri, M. Kahlaoui, S. Soudani, C. Ben Nasr J. Mol. Struct 1170, $30(2018)$

15. K. D. Karlin, S. Kaderli and A. D. Zuberber. Acc. Chem. Res. 30, 139 (1997)

16. P. A. Vigato, S. Tamburini, and D. E. Fenton. Coord. Chem. Rev. 106, 25 (1990)

17. R.Guptam, S.Mukherjee and R.Mukherjee. J. Chem. Dalton Trans. 4025 (1999)

18. U. Schülke, R. Kayser. Z. Anorg. Allg. Chem. 531, 167 (1985)

19. Z. Otwinowski, Z. Minor. In Methods in Enzymology, Carter C W and Sweet R M (ed) (Academic Press London) A 276, 307 (1977)

20. A. Altomare, M. C. Burla, M. Camalli, G. L. Cascarano, C. Giacovazzo, A. Guagliardi, A. Grazia, G. Moliterni, G. Polidori, R. J. Spagna, SIR97: a new tool for crystal structure determination and refinement, J. App. Cryst. 32, 115 (1999)

21. G. M Sheldrick, SHELXTL Version 2014/7. http://shelx.uniac.gwdg.de/SHELX/index.php.

22. L. J. Farrugia, $\operatorname{Win} G X$ suite for small-molecule single-crystal crystallography, J. Appl. Crystallogr. 32, 837 (1999)

23. K. Brandenburg (1998). Diamond Version 2.0 Impact GbR. Bonn, Germany.

24. Bruker WINFIT Program’ Bruker Rep. 140, 43 (1994)

25. W. Baur, Acta Cryst. B30, 1191 (1974)

26. L. Khedhiri, E. Jeanneau, F. Lefebvre, M. Rzaigui, C. Ben Nasr. J. Mol. Struct. 1105, $87(2016)$

27. L. Khedhiri, E. Jeanneau, F. Lefebvre, M. Rzaigui, C. Ben Nasr. J. Chem. Sci. 128, 1037 (2016) 
28. L. Khedhiri, A. Hamdi, S. Soudani, W. Kaminsky, F. Lefebvre, M. Wojtas, C. Ben Nasr. J. Mol. Struct. 1171, 429 (2018)

29. C. Jelsch, S. Soudani, C. Ben Nasr IUCrJ, 2, 327 (2015)

30. C. Jelsch, C. Ejsmont, L. Huder IUCrJ, 1, 119 (2014).

31. H. Ettis, H. Nä̈li, T. Mhiri, J Solid State Chem 179, 3107 (2006)

32. L. Le Van-Jodin, F. Ducroquet, F. Sabary, I. Chevalier, Solid State Ionics 253, (2013)

33. M. Ferhi, K. Horchani-Naifer, Kh. Ben Saad, M. Férid, Physica B 407, 2593 (2012)

34. A. Hamdi, L. Khedhiri, M. Kahlaoui, S. Soudani, V. Ferretti, F. Lefebvre, C. Jelsch, E. Wenger, C. Ben Nasr, J. Mol. Struct. 1170, 30 (2018)

35. W. W. Brand, M. E Cuvelier, C. Berset lebensm-Wissu Technol 28, 25 (1995)

36. R. Roberta, N. Pellegrini, A. Pannala, M. Yang, C. Rice-Evan. Free Radical Biology and Medicine 26, 1231 (1999)

37. W. Binsan, S. Benjakul, W. Visessanguan, S. Roytrakul, M. Tanaka, H. Kishimura Food Chemistry 106, 185 (2008) 


\section{Supplementary Information}

Structural, NMR, IR, Hirshfeld Surface, Electrochemical and in Vitro

Biochemical Investigations of a New Organic Cyclohexaphosphate, $\left(\mathrm{C}_{6} \mathrm{H}_{6} \mathrm{ClFN}\right)_{4}(\mathrm{Li})_{2}\left(\mathrm{P}_{6} \mathrm{O}_{18}\right)\left(\mathrm{H}_{2} \mathrm{O}\right)_{4}$

L. Khedhiri ${ }^{\mathrm{a}}$, A. Gannouni ${ }^{\mathrm{a}}$, M. Khalfaoui ${ }^{\mathrm{b}}$, C. Jelsch ${ }^{\mathrm{c}}$, V. Ferretti ${ }^{\mathrm{d}}$, F. Lefebvre ${ }^{\mathrm{e}}$, C. Ben Nasr ${ }^{\mathrm{a}}{ }^{*}$

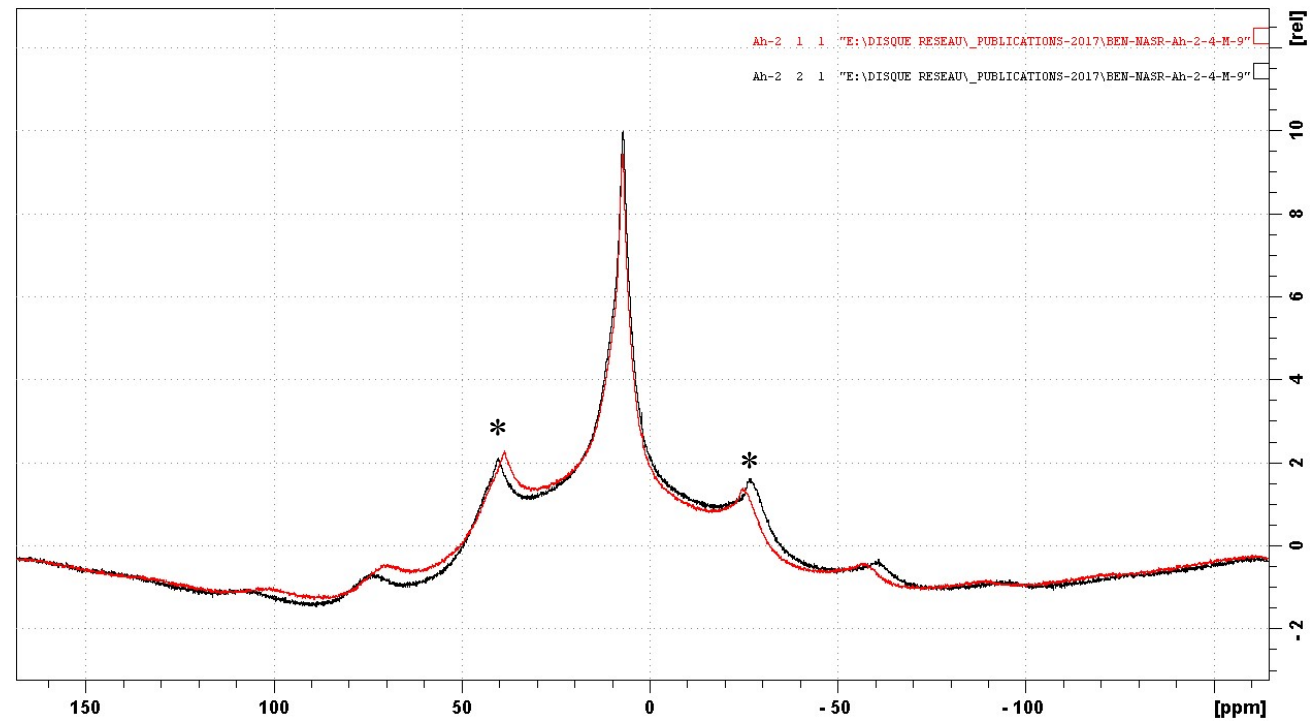

Fig. S1: ${ }^{1} \mathrm{H}$ MAS NMR spectrum of $\left(\mathrm{C}_{6} \mathrm{H}_{6} \mathrm{ClFN}\right)_{4}(\mathrm{Li})_{2}\left(\mathrm{P}_{6} \mathrm{O}_{18}\right)\left(\mathrm{H}_{2} \mathrm{O}\right)_{4}$. * spinning side bands. 


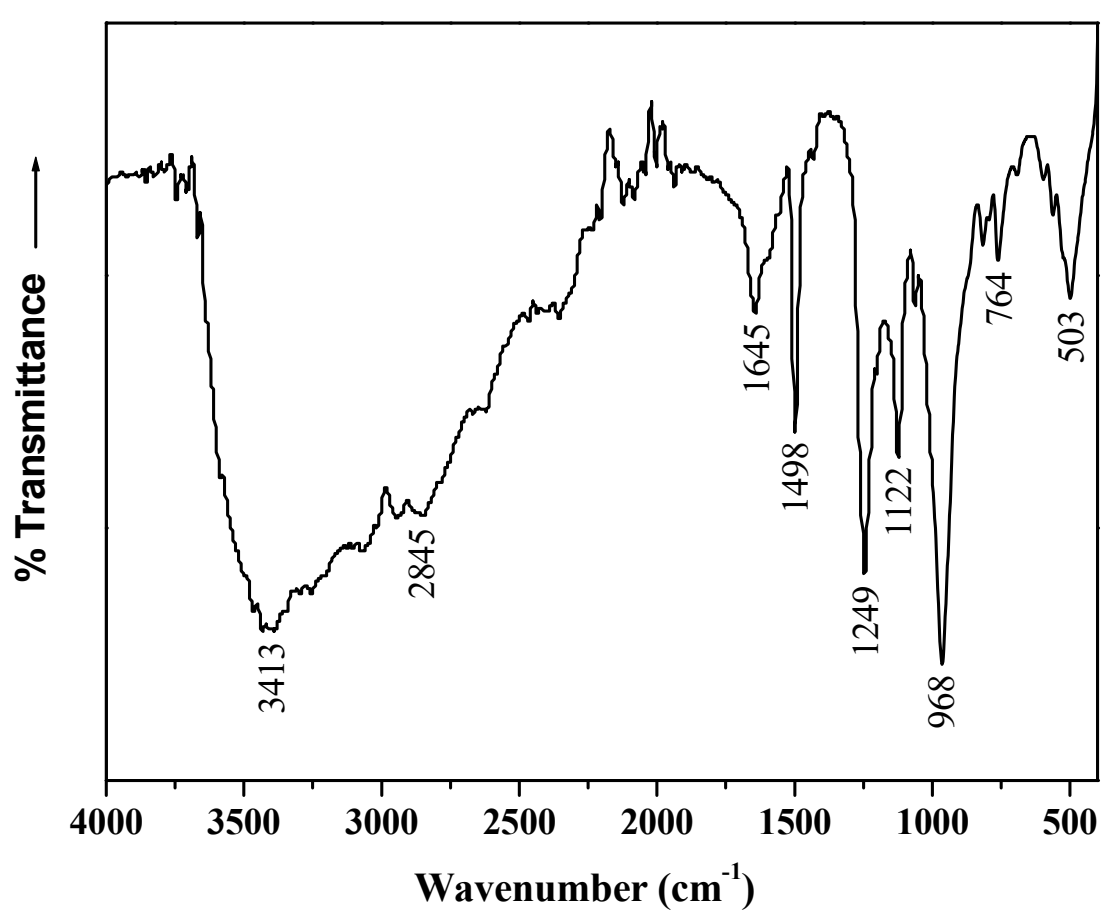

Fig. S2: Infrared spectrum of $\left(\mathrm{C}_{6} \mathrm{H}_{6} \mathrm{ClFN}\right)_{4}(\mathrm{Li})_{2}\left(\mathrm{P}_{6} \mathrm{O}_{18}\right)\left(\mathrm{H}_{2} \mathrm{O}\right)_{4}$. 


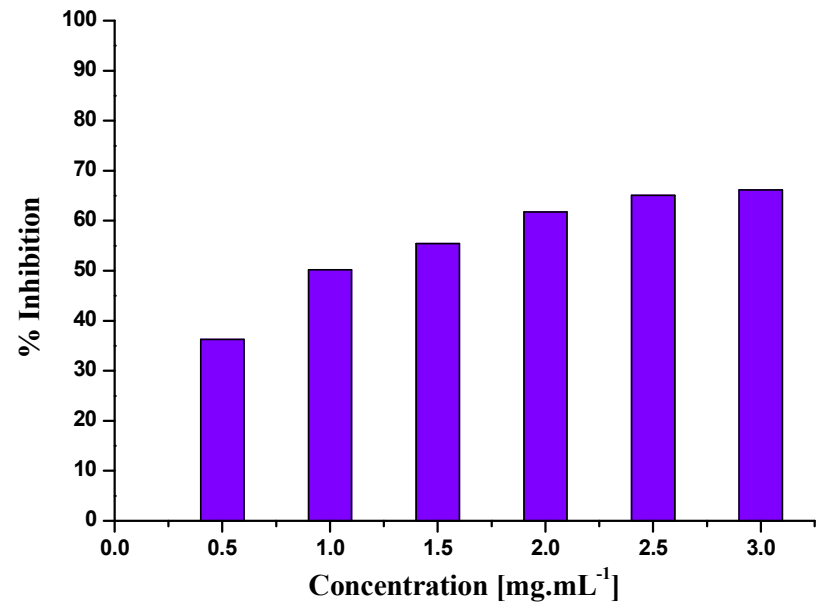

Fig. S3: DPPH radical scavenging activity at different concentrations of $\left(\mathrm{C}_{6} \mathrm{H}_{6} \mathrm{ClFN}\right)_{4}(\mathrm{Li})_{2}\left(\mathrm{P}_{6} \mathrm{O}_{18}\right)\left(\mathrm{H}_{2} \mathrm{O}\right)_{4}$.

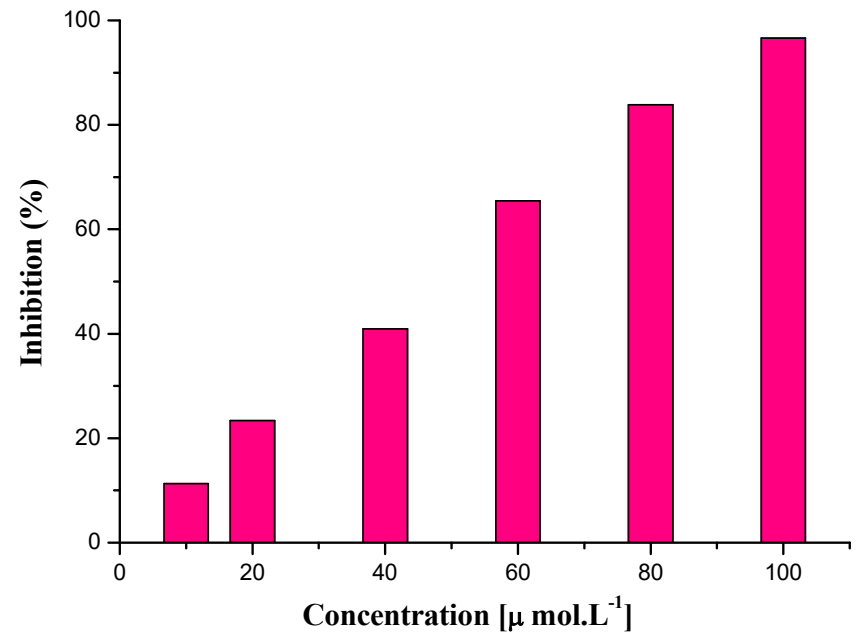

Fig. S4: DPPH radical scavenging activity at different concentrations of trolox 
Table S1. Crystallographic data and structure refinement of $\left(\mathrm{C}_{6} \mathrm{H}_{6} \mathrm{ClFN}\right)_{4}(\mathrm{Li})_{2}\left(\mathrm{P}_{6} \mathrm{O}_{18}\right)\left(\mathrm{H}_{2} \mathrm{O}\right)_{4}$.

\begin{tabular}{|c|c|}
\hline Empirical formula & $\left(\mathrm{C}_{6} \mathrm{H}_{6} \mathrm{ClFN}\right)_{4}(\mathrm{Li})_{2}\left(\mathrm{P}_{6} \mathrm{O}_{18}\right)\left(\mathrm{H}_{2} \mathrm{O}\right)_{4}$. \\
\hline Formula weight $\left[\mathrm{g} \mathrm{mol}^{-1}\right]$ & 1146.03 \\
\hline Crystal color, habit & colorless, block \\
\hline Crystal temperature $[\mathrm{K}]$ & 295 \\
\hline Crystal size $\left[\mathrm{mm}^{3}\right]$ & $0.52 \times 0.35 \times 0.09$ \\
\hline Radiation, wavelength $[\AA ̊]$ & $\operatorname{MoK\alpha }, 0.71073$ \\
\hline Crystal system & triclinic \\
\hline Space group & P-1 \\
\hline \multicolumn{2}{|l|}{ Unit-cell dimensions: } \\
\hline$a, b, c[\AA]$ & $7.916(2), 15.095(4), 18.767(4)$ \\
\hline$\alpha, \beta, \gamma\left[^{\circ}\right]$ & $96.322(2), 91.134(2), 90.100(1)$ \\
\hline Volume $\left[\AA^{3}\right]$ & $2228.42(9)$ \\
\hline$Z$ & 2 \\
\hline Density calc. $\left[\mathrm{g} \mathrm{cm}^{-3}\right]$ & 1.708 \\
\hline Absorption coefficient $\mu\left[\mathrm{mm}^{-1}\right]$ & 0.581 \\
\hline$F(000)$ & 1160 \\
\hline$\theta$-Range for data collection $\left[{ }^{\circ}\right]$ & 2.574 to 30.001 \\
\hline Limiting indices & $-11 \leq h \leq 11,-21 \leq k \leq 21,-26 \leq l \leq 26$ \\
\hline Reflections collected/unique & $29018 / 10014\left(R_{\text {int }}=0.03\right)$ \\
\hline Refinement method & Full-matrix least-squares on $F^{2}$ \\
\hline Data, restrains, parameters $(\mathrm{I}>2 \sigma)$ & $10014,3,675$ \\
\hline Goodness-of-fit on $F^{2}$ & 1.035 \\
\hline$R$ indices (all data, on $F^{2}$ ) & $R=0.0439, w R=0.1131$ \\
\hline$\Delta \rho(\min , \max )\left[\mathrm{e} \AA^{-3}\right]$ & -0.553 and 0.617 \\
\hline
\end{tabular}


Table S2. Structural parameters for hydrogen bonding interactions $\left(\AA\right.$, $\left.^{\circ}\right)$ in $\left(\mathrm{C}_{6} \mathrm{H}_{6} \mathrm{ClFN}\right)_{4}$ (Li) $)_{2}\left(\mathrm{P}_{6} \mathrm{O}_{18}\right)\left(\mathrm{H}_{2} \mathrm{O}\right)_{4}$.

\begin{tabular}{|c|c|c|c|c|}
\hline$D-\mathbf{H} \cdots A$ & $D-\mathbf{H}$ & $D \cdots A$ & $\mathbf{H} \cdots A$ & $D-\mathbf{H} \cdots A$ \\
\hline $\mathrm{N} 1-\mathrm{H} \ldots \mathrm{O} 14$ & $0.93(3)$ & $2.774(2)$ & $1.92(3)$ & $150(3)$ \\
\hline N1-H ...O8 & $0.92(3)$ & $2.872(2)$ & $1.97(3)$ & $168(3)$ \\
\hline N2-H ...O5 & $0.92(3)$ & $2.794(2)$ & $1.94(3)$ & $154(3)$ \\
\hline N3-H ...O3W & $0.86(3)$ & $2.738(3)$ & $1.89(3)$ & $167(3)$ \\
\hline N4-H ...O13 & $0.88(3)$ & $2.792(2)$ & $1.99(3)$ & $150(3)$ \\
\hline N4-H ...O4W & $0.94(3)$ & $2.737(3)$ & $1.82(3)$ & $163(3)$ \\
\hline O1W-H...O10 & $0.85(2)$ & $3.012(2)$ & $2.27(3)$ & $146(2)$ \\
\hline O1W-H...O14 & $0.85(2)$ & $3.021(2)$ & $2.33(3)$ & $138(2)$ \\
\hline O2W-H...O1 & $0.77(5)$ & $3.012(2)$ & $2.33(4)$ & $147(4)$ \\
\hline $\mathrm{O} 2 \mathrm{~W}-\mathrm{H} \ldots \mathrm{O} 5$ & $0.77(5)$ & $3.035(2)$ & $2.45(4)$ & $134(4)$ \\
\hline $\mathrm{N} 2-\mathrm{H} \ldots \mathrm{O} 17^{\mathrm{i}}$ & $0.95(3)$ & $2.904(2)$ & $1.95(3)$ & $170(3)$ \\
\hline $\mathrm{N} 3-\mathrm{H} . . . \mathrm{O} 13^{\mathrm{i}}$ & $0.95(2)$ & $2.760(2)$ & $1.81(3)$ & $173(2)$ \\
\hline N1-H...O18i & $0.87(3)$ & $2.680(2)$ & $1.82(3)$ & $172(3)$ \\
\hline $\mathrm{O} 2 \mathrm{~W}-\mathrm{H} . . . \mathrm{O} 7^{\mathrm{i}}$ & $0.82(3)$ & $2.711(2)$ & $1.89(3)$ & $175(3)$ \\
\hline $\mathrm{N} 2-\mathrm{H} \ldots \mathrm{O}^{\mathrm{i}}$ & $0.98(3)$ & $2.691(2)$ & $1.72(3)$ & $170(2)$ \\
\hline $\mathrm{N} 4-\mathrm{H} \ldots \mathrm{O} 4^{\mathrm{ii}}$ & $0.92(2)$ & $2.763(2)$ & $1.86(2)$ & $166(2)$ \\
\hline $\mathrm{N} 3-\mathrm{H} . . . \mathrm{O} 4^{\mathrm{ii}}$ & $0.89(3)$ & $2.828(2)$ & $2.07(3)$ & $142(3)$ \\
\hline C20-H...O9 ${ }^{\mathrm{ii}}$ & 0.93 & $3.522(3)$ & 2.61 & 164 \\
\hline O3W-H...O1W ${ }^{\mathrm{iii}}$ & $0.87(5)$ & $2.835(3)$ & $1.96(5)$ & $176(5)$ \\
\hline O1W-H...O16 $6^{\mathrm{iii}}$ & $0.84(3)$ & $2.727(2)$ & $1.90(3)$ & $166(3)$ \\
\hline O4W-H...O2W ${ }^{\text {iii }}$ & $0.83(4)$ & $2.836(3)$ & $2.01(4)$ & $168(4)$ \\
\hline $\mathrm{O} 4 \mathrm{~W}-\mathrm{H} \ldots \mathrm{O} 5^{\text {iv }}$ & $0.82(2)$ & $2.920(2)$ & $2.21(3)$ & $144(2)$ \\
\hline
\end{tabular}

Equivalent positions : (i) $\mathrm{x}-1, \mathrm{y}, \mathrm{z}$; (ii) $\mathrm{x}, \mathrm{y}+1, \mathrm{z}$; (iii) $1-\mathrm{x} 1,1-\mathrm{y},-\mathrm{z}$; (iv) $\mathrm{x}+1, \mathrm{y}+1, \mathrm{z}$ 